\title{
Institutional Choice and Targeted Killing: A Comparative Perspective
}

\author{
[Forthcoming, 94 Tulane Law Review, _ (2020)] \\ Elad D. Gil
}

For over a decade, the use of targeted killing has been one of the most controversial issues in counterterrorism policy and law. One longstanding debate over this tactic concerns the allocation of decision-making and oversight authority among the branches of government. As attempts to settle this debate through textual and historical sources yield indeterminant answers, scholars tend to examine them through a functionalist prism, asking what institutional structures best serve the interests of national security while ensuring adequate accountability and preventing unnecessary force.

This article, retaining that functionalist framing of that issue, will approach the question through a comparative law analysis. Three of the countries most heavily engaged in global counterterrorism - the U.S., the U.K., and Israel - have adopted substantially different approaches for regulating counterterrorism targeting, each according a primary supervisory role to a different governmental actor: the Executive in the U.S., Parliament in the U.K., and the fudiciary in Israel. This article describes, compares, and critically analyzes these approaches. Drawing on comparative institutional analysis theory, it then examines the findings and reaches three main conclusions. First, that in light of the judiciary's unique structural perspective and expertise, some judicial involvement in developing the legal standard that guides and constrains government action is desirable. Second, that suboptimal decision-making and illegality due to executive bias are more likely to occur where the executive is accountable only to its own internal oversight mechanisms. And third, that in both presidential and parliamentarian systems, legislators do not have and are unlikely to have any sort of meaningful influence on executive behavior in this domain. The article concludes by suggesting a few possible institutional reforms.

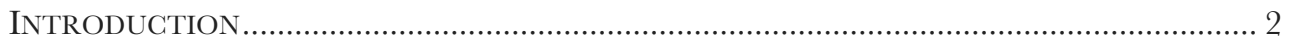

I. FRAMING THE PROBLEM: THE UNIQUENESS OF COUNTERTERRORISM TARGETING....... 8

A. War is distinguishable from peace? ................................................................. 9

B. International law imposes constraints on executive power? .................................. 11

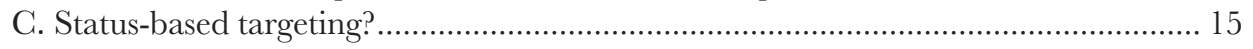

* Post-Doctoral Fellow, Mishael Cheshin Center, Hebrew University, Faculty of Law; Fellow, the Abba Eban Institute for international Diplomacy, the Interdisciplinary Center Herzliya. For helpful comments and suggestions, I am indebted to Shira Anderson, Ziv Bohrer, Curt Bradley, Madeline Morris, Jeff Powell, Christine Ryan, Ori Sharon, Yahli Shereshevsky, and the participants of the International Law Weekend of the American Branch of the International Law Association, the Doctoral Scholarship Conference at Yale Law School, and the Young Researchers Workshop on Terrorism and Belligerency at the Minerva Center for the Rule of Law under Extreme Conditions, Haifa University. This article benefited from talks and interviews I conducted with lawyers and officers of the Israeli Defense Forces. I wish to thank them for their time and cooperation. 
II. Regulating TARgeted Killing IN THE U.S, THE U.K., AND ISRAEL ..................... 16

A. The United States: executive primacy ............................................................... 16

1. The historical evolution of executive unilateralism over targeting................................... 18

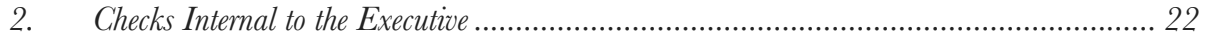

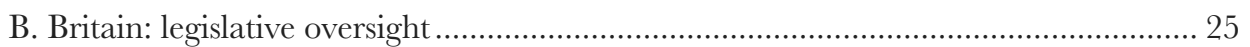

1. The Parliament's drone inquiries .............................................................................. 27

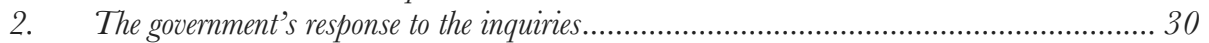

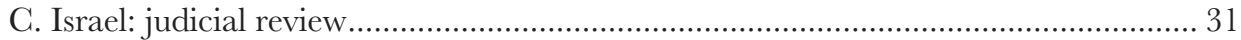

1. The Targeted Killing Case...................................................................................... 34

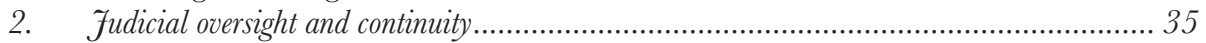

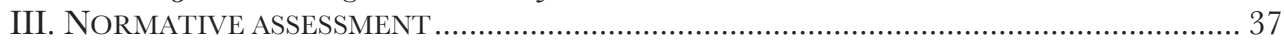

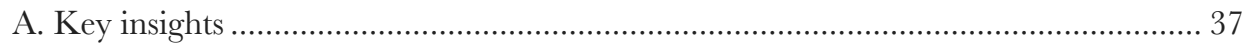

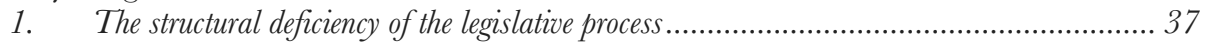

2. The inadequacy of self-regulatory regimes ............................................................. 40

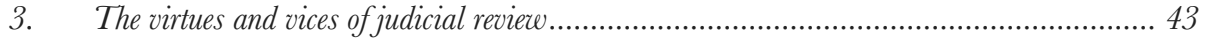

B. Parameters for possible institutional reforms....................................................... 46

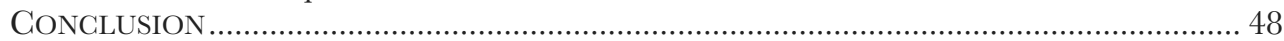

\section{INTRODUCTION}

In March, 2018, a number of human rights organizations issued a joint statement expressing concerns over recent changes to U.S. policy on the use of force in counterterrorism missions. ${ }^{1}$ The statement warned that President Trump's departures from his predecessor's regulatory framework, including the relaxation of high-level vetting requirements and the removal of several limiting conditions, "will lead to an increase in unlawful killings." 2 While this assertion may be debatable, at a minimum, the institutionalization of targeted killing $^{3}$ as a policy tool indeed raises a range of legal and ethical questions, many of which remain in dispute notwithstanding years of debate and commentary. It is uncertain, to take a few examples, what international law rules - either those applicable in wartime or in peace-time - govern uses of force undertaken away from "hot" battlefields; ${ }^{4}$ what conditions must be met

1 See, NGO Statement on Reported Changes to U.S. Policy on Use of Armed Drones and Other Lethal Force (Mar. 7, 2018), https://www.hrw.org/news/2018/03/07/ngostatement-reported-changes-us-policy-use-armed-drones-and-other-lethal-

force\#footnote1_tkqk6e2.

${ }^{2} I d$.

3 This article uses the terms "targeted killing and "counterterrorism targeting" interchangeably. I draw on Nils Melzer's authoritative definition of targeted killing as "the use of lethal force attributable to a subject of international law with the intent, premeditation, and deliberation to kill individually selected persons who are not in the physical custody of those targeting them." Nils Melzer, Targeted Killings in International Law 5 (2008).

4 Compare, e.g., John O. Brennan, Assistant to the President for Homeland Sec. \& Counterterrorism, Remarks at the Harvard Law School: Strengthening our Security by Adhering to our Values and Laws (Sept. 16, 2011) reprinted in KENNETH ANDERSON AND 
to permit targeting under any of these legal regimes $;{ }^{5}$ what source of domestic law provides legal authority to single out specific individuals for lethal targeting; ${ }^{6}$ whether domestic law safeguards on life and liberty apply to those targeted and others who may suffer incidental harm; ${ }^{7}$ how should potential strategic benefits and harms be weighted; and whether this form of lethal force is justified from a moral perspective. ${ }^{8}$

Benjamin Wittes, Speaking the Law: The Obama Administration's AdDresses on NATIONAL SECURITY LAW 450 (2015) (" [t] he United States does not view our authority to use military force against al-Qa'ida as being restricted solely to 'hot' battlefields like Afghanistan.") with Report of the Special Rapporteur on Extrajudicial, Summary or Arbitrary Executions, Study on Targeted Killings, Human Rights Council, \ 52-53, U.N. Doc. A/HRC/ 14/24/Add.6 (May 28, 2010) (by Philip Alston) (questioning whether the U.S. may lawfully invoke IHL to justify uses of force outside the theaters of war in Iraq and Afghanistan). See also Jennifer Daskal, The Geography of the Battlefield: A Framework for Detention and Targeting Outside the 'Hot' Conflict Zone, 161 U. PA. L. REV. 1165, notes 9-10 (2013) (citing additional literature on this controversy).

5 See generally MELzER, supra note 3; David Kretzmer, Targeted Killing of Suspected Terrorists: Extra-fudicial Executions or Legitimate Means of Defence?, 16 Eu.J. INT'L. L. 171 (2005).

6 See generally $\mathrm{H}$. JeFFerson POWELl, TARgeting Americans: the CONSTITUTIONALITY OF THE U.S. DRONE WAR (2016).

${ }^{7}$ One point of disagreement is whether the protections afforded under the Fourth and Fifth Amendments attach to targeted individuals who are U.S. citizens. Compare White House Press Release, Remarks of President Barack Obama at the National Defense University (May 23, 2013), (https://www.nytimes.com/2013/05/24/us/politics/transcript-of-obamasspeech-on-drone-policy.html) (hereinafter, Obama May 2013 speech) ("I do not believe it would be constitutional for the government to target and kill any U.S. citizen - with a drone, or with a shotgun - without due process"); U.S. Dep't of Justice, White Paper (2011) (assuming that the Constitution protects a U.S. citizen who is a senior operational leader of al-Qaeda or associated forces; articulating a relatively permissive standard for satisfying Due Process protections); with POWELL, supra note 6, at 137-46 (criticizing the administration's position; arguing that Constitutional prohibitions such as those afforded under the Fourth and Fifth Amendments do not limit the executive war-making authority); John Yoo, The Real Problem with the Obama Administration's Drone Memo, NAT'L REview (Jun. 26, 2014) https://www.nationalreview.com/corner/real-problem-obama-administrations-drone-

memo-john-yoo/ ("[i]n wartime, as our presidents, Congress, and courts have long recognized, our military cannot be hamstrung by judicial notions of due process in its selection of targets and its conduct of hostilities"). A similar question arises with respect to the applicability of statutory and administrative prohibitions to the government war authority. See Memorandum from David J. Barron, Acting Assistant Att'y Gen., Office of Legal Counsel, to the Att'y Gen., Re: Applicability of Federal Criminal Laws and the Constitution to Contemplated Lethal Operations Against Shaykh Anwar al-Aulaqi, at 1 (Jul. 16, 2010) (discussing the prohibition on killing of U.S. nationals abroad under 18 U.S.C. § 1119(b) and the ban on assassination under Executive Order No. 12333).

8 See generally Daniel Statman, Targeted Killing, 5 Theoretical InQUiRIes IN LaW 179 (2004); Jeremy Waldron, Fustifying Targeted Killing with a Neutral Principle?, in TARGETED KILLINGS: LAW AND MORALITY IN AN ASYMMETRICAL WORLD (Claire Finkelstein et al eds., 2012). 
What the human rights organizations' critique failed to appreciate, however, was that the regulatory changes authorized by President Trump did not diverge from his predecessor's fundamental legal positions. ${ }^{9}$ In fact, the Obama administration's interpretation of the legal framework governing its counterterrorism policies largely relied on the same legal positions of the Bush administration. ${ }^{10}$ By focusing on Trump, the organizations' statement missed the fact that the defining feature of the United States' use of targeted killing is not the regulatory scheme or underlying legal theory adopted by any particular president but, rather, the predominance of the executive branch in decision-making. Since 1998, when President Clinton first asserted authority to order the killing of alleged terrorists abroad, neither Congress nor the judiciary has had any noticeable impact on presidential behavior in this context, regardless of who occupied the White House. Indeed, axiomatic in U.S. constitutional law that the President, as Chief Executive and Commander-in-Chief, possesses broad - albeit vague - powers in the areas of national security and foreign affairs. ${ }^{11}$ Especially during the $20^{\text {th }}$ century, the presidency gradually sidelined the other branches of government in those fields, circumventing whatever balancing and checking functions those institutions might otherwise have performed. ${ }^{12}$ For countries that enshrine separation of powers, the fact that a single branch of government - the Executive- has come to have virtually full autonomy over all of the difficult

${ }^{9}$ For the Trump administration's legal and policy views, see generally the White House, Report on the Legal and Policy Frameworks Guiding the United States' Use of Military Force for National Security Operations, 3 (Mar. 13, 2018), https://www.lawfareblog.com/document-white-house-legal-and-policy-frameworks-usemilitary-force (hereinafter, 2018 Presidential Report on National Security). The report draws on and adopts most of the positions of an equivalent submitted by the Obama administration. See the White House, Report on the Legal and Policy Frameworks Guiding the United States' Use of Military Force and Related National Security Operations (Dec. 5, 2016) https://www.justsecurity.org/wp-content/uploads/2016/12/framework.Report_Final.pdf (hereinafter, 2016 Presidential Report on National Security).

10 See, e.g., Jack Goldsmith, Power and Constraint: The Accountable PrEsidency AFTeR 9/11 5-20 (2012) (comparing Presidents Bush and Obama's counterterrorism policies).

11 The U.S. Constitution does not elucidate what powers are encompassed by the President's role as Chief Executive and Commander-in-Chief. See U.S. CONST. art. II, $\S \S$ 2, 3. See also H. Jefferson Powell, The President's Authority over Foreign Affairs: An Executive Branch Perspective, 67 GeO. WASH. L. Rev. 527, 529 (1999) (concluding that the President has "primary constitutional authority over the conduct of foreign affairs and the protection of national security;" yet noting that "constitutional law in this area remains uncertain, perhaps more so than on most other topics"); LOUIS HENKIn, CONSTITUTIONALISM, DEMOCRACY, AND FOREIGN AFFAIRS, xi (1990) (referring to a "twilight zone" of foreign affairs powers in the U.S. Constitution);

12 See generally Arthur M. Schlesinger JR., The Imperial Presidency (2004 ed.) (describing the gradual expansion of presidential power over foreign affairs). 
legal, moral and policy questions raised by the use of targeted killings is a cause for some disquiet. ${ }^{13}$

In legal doctrine and scholarship, executive unilateralism in counterterrorism policy has been conceptualized and debated largely in terms of the constitutional assignment of authority to initiate war and regulate the use of force ("the war powers debate"). ${ }^{14}$ Consistent with this framing, as "the Constitutional text does not explain the scope of the two [political] branches' respective powers, or how to resolve possible conflicts in their exercise," 15 debates often turn on functional considerations: instead of debating what the drafters meant or what the text says, scholars have focused on asking what allocation of authority would work best. ${ }^{16}$ In the targeted killing context, a functionalist analysis thus focuses on three key questions: (1) What are the implications of an executive branch acting on its own without meaningful external checks? (2) Does legislative or judicial involvement make things

13 Separating government powers is itself a mean to promote other social ends. See, e.g., Bruce Ackerman, The New Separation of Powers, 113 HARV. L. REV. 633 (2000) (identifying three ideals underlying the separation of powers: democracy, professionalism, and the protection of fundamental rights).

14 U.S. courts have dismissed several challenges to the President targeting authority under the theory that courts lack constitutional authority and institutional competence to assess wartime decisions. See El-Shifa Pharm. Indus. Co. v. United States, 55 Fed. Cl. 751 (Fed. Cl. 2003), affd, 378 F.3d 1346 (Fed. Cir. 2004); El-Shifa Pharm. Indus. Co. v. United States, 402 F. Supp. 2d 267 (D.D.C. 2005), affd, 559 F.3d 578 (D.C. Cir. 2009), affd on reh'g en banc, 607 F.3d 836 (D.C. Cir. 2010); Al-Aulaqi v. Obama, 727 F. Supp. 2d 1 (D.D.C. 2010); Al-Aulaqi v. Panetta, 35 F. Supp. 3d 56 (D.D.C. 2014); Jaber v. United States (Jaber I), 155 F. Supp. 3d 70 (D.D.C. 2016), affd, 861 F.3d 241 (D.C. Cir. 2017), cert. denied, 138 S. Ct. 480 (2017). The bulk of the scholarly work on the topic assumed that the authority to targeted terrorists stems from the President war authority. See, e.g., Curtis A. Bradley and Jack L. Goldsmith, Obama's AUMF Legacy, 110 AM. J. INT'L. L. 628, 641-45 (2016); Gregory S. McNeal, Targeted Killing and Accountability, 102 GEO. L.J. 681 (2014); Stephen I. Vladeck, Targeted Killing and Fudicial Review, 82 GEO. WASH. L. REV. Arguendo 11 (2014); Matthew Craig, Targeted killing, procedure, and false legitimation, 35 CARDOZO L. REV. 2349 (2014); Jameel Jaffer, Fudicial Review of Targeted Killings, 126 HARV. L. REV. F. 185 (2013); Gabriella Blum \& Philip Heymann, Law and Policy of Targeted Killing, 1 HaRv. NAT'L SEC. J. 145, 150 (2010); Monica Hakimi, A Functional Approach to Targeting and Detention, 110 MicH L. REV. 1365, 136768 (2012).

15 Powell, supra note 6, at 43.

16 See, e.g., Ganesh Sitaraman \& David Zionts, Behavioral War Powers, 90 N.Y.U. L. Rev. 516 (2015) (drawing on behavioral economics literature for analyzing the constitutional design of war powers); John Yoo \& Jide Nzelibe, Rational War and Constitutional Design, 115 YALE L.J. 2512 (2006) (employing a functional approach to justify unilateral presidential authority over war-making); Deborah N. Pearlstein, Form and Function in the National Security Constitution, 41 CONN. L. REV. 1549 (2009) (invoking functionalism to argue for multi-branch participation in national security decision-making); ERIC A. POSNER \& ADRIAN VERMEULE, TERROR IN THE BALANCE: SECURITY, LiberTy, AND THE COURTS 29-31 (2007) (asserting that the executive has institutional advantages in making tradeoffs between security and liberty in wartime). 
better or worse, or perhaps change nothing in practice? And, (3) is a system of checks and balances internal to the executive an appropriate substitute for external checks?

This article confronts these questions by pursuing a comparative law analysis. Since the early 2000s, there has been a significant increase in the use of targeted killing worldwide. ${ }^{17}$ The three states most active in this field - the U.S., the U.K., and Israel - have taken very different approaches to the allocation of decision-making authority over such use of force. In the U.S., as noted, the President relies on multiple agencies and internal checking mechanisms to regulate counterterrorism targeting, while both Congress and the courts hesitate to weigh in. In Britain, the executive initially acted in a similar fashion but was challenged by Parliament, which invoked its oversight authority to probe - and ultimately contest - the Executive's legal positions. ${ }^{18}$

17 The expansion of targeted killings has several dimensions. First, a growing number of countries use or contemplate this tactic. To date, the growing list of countries practicing such targeting includes the United States, Britain, Russia, France, Colombia, Turkey, Israel, Nigeria, Pakistan, Iraq, Iran, UAE, and Saudi Arabia. See Institute for the Study of Counterterrorism \& Unconventional Warfare, The Cross-border Counterterror Operations Database https://iscuw.org/operations (last visited Nov. 18, 2018); New America Foundation, International Security Data Base https://www.newamerica.org/in-depth/world-of-drones/ (last visited Nov. 19, 2018); Joanna Frew, Drone Wars: the Next Generation, DronE WARs UK, 8-27 (May, 2018) https://dronewarsuk.files.wordpress.com/2018/05/dw-nextgenerationweb.pdf.; The Bureau of Investigative Journalism, Drone Warfare https://www.thebureauinvestigates.com/projects/drone-war (last visited Nov. 19, 2018). See also Martin Senn \& Jodok Troy, The Transformation of Targeted Killing and International Order, 38 Contemp. Security PoL'Y, 175, 190 (2017); Robert Chesney, The French War on Terrorism: Targeting French Islamic State Fighters through Iraqi Forces, LAWFARE (May 30, 2017, 7:00 AM) https://www.lawfareblog.com/french-war-terrorism-targeting-french-islamic-state-fightersthrough-iraqi-forces. In addition, a total of at least 30 states and non-state actors currently possess armed drone technology as compared to only three a decade ago. See New America Foundation, Who has what: Countries with Armed Drones https://www.newamerica.org/indepth/world-of-drones/3-who-has-what-countries-armed-drones/ (last visited Nov. 18, 2018) See also Frew, supra, at 8-27; Michael C. Horowitz \& Matthew Fuhrmann, Droning on: Explaining the Proliferation of Unmanned Aerial Vehicles (October 1, 2015). Available at SSRN: https://ssrn.com/abstract=2514339.

Second, the use of targeted killing among the states that already practice it has extended to new contexts and new arenas. For example, the U.S. has carried out strikes in at least seven different countries in the context of the 'war on terror', including in areas remote from recognizable war zones. Other states, such as Turkey and Iraq, have carried out strikes within their own territories. See Frew, supra, at 6.

And finally, there is the increasing export of armed drones by new actors such as China, Turkey, and Iran, with the latter reportedly transferring the technology to non-state armed groups. Id., at 14 .

18 Joint Comm. on Human Rts., Second Report: The Government's Policy ON THE USE OF DRONES FOR TARGETED Killing, HL 141, HG 574 (U.K.) (hereinafter, fCHR Drones Report); Intel. \& SEC. Comm., UK Lethal Drone Strikes In Syria (2017) HC 1152 [U.K.] (hereinafter, ISC Report). 
In Israel, the Supreme Court has articulated and applied a judge-made legal standard for counterterrorism targeting. ${ }^{19}$ These distinct approaches provide an empirical basis for a comparative analysis of institutional structures for the regulation of counterterrorism targeting.

Comparative analysis is especially useful in this context because existing literature lacks systematic and analytic evaluation of current practices against real alternatives. ${ }^{20}$ For example, while commentators have lamented judicial abdication ${ }^{21}$ or urged greater Congressional input, ${ }^{22}$ there has been little basis for assessing whether proposed alternatives are politically feasible or normatively attractive. Only by juxtaposing real regulatory mechanisms, examining the institutional and practical obstacles they have faced, and considering their successes and failures, may we assess whether the current practice should be reformed.

Targeted killing of specific, preidentified suspected terrorists is a deeply contested practice. In comparatively evaluating the three models, I take no normative position on the underlying morality or legality of the practice under international or domestic law. ${ }^{23}$ I take the decision of a growing number of states to resort to this form of lethal force as a given, and then ask what institutional structures would yield the best results in terms of the quality of decision-making, adherence to the rule of law, and prevention of unnecessary deprivation of life. In evaluating each model, I employ 'comparative institutional analysis', a conceptual framework for assessing government and public institutions based on their relative structural strengths and weaknesses and actual performance. ${ }^{24}$

19 HCJ 769/02 The Public Committee Against Torture in Israel v. Government of Israel, 57(6) PD 285 [2006] (Isr.). English version available at http://elyon1.court.gov.il/VerdictsSearch/EnglishStaticVerdicts.html (hereinafter, the Targeted Killing case).

20 To be sure, scholars have analyzed counterterrorism targeting from a comparative lens in different contexts, but no one has considered the institutional aspects of the variance regarding the regulation of it.

21 See, e.g., Jameel Jaffer, The Drone Memos: Targeted Killing, Secrecy, And THE LAW (2016).

22 See, e.g., Cato Handbook for Policymakers (8 ${ }^{\text {th }}$. Ed., 2017) (calling Congress to "consider suspending targeted killing in Pakistan, Yemen, and Somalia, at least until the executive branch provides studies or public testimony explaining why the policy makes sense in each nation").

${ }^{23}$ For a comprehensive analysis of key areas of disagreement see TARGETED KILLINGS: LAW AND MORALITY IN AN ASYMMETRICAL WORLD (Claire Finkelstein et al eds., 2012).

24 See generally Neil K. Komesar, Imperfect Alternatives: Choosing Institutions in Law, Economics, And Public Policy (1994). To clarify, this article integrates comparative institutional analysis, in which the units of comparison are different institutions of government and comparative law analysis, in which the units of analysis are different countries (here, the U.S., the U.K., and Israel). 
This analysis produces three main insights. First, the model of executive autonomy - as practiced in the U.S. - renders only weak constraints on executive power and is susceptible to abuse and multiple forms of bias. The incentive structure of executive decision-makers typically favors the enhancement of executive power; internal checks and balancing mechanisms are too weak and vulnerable to overcome that tendency. As a result, internal rules and procedures produced by the executive to regulate executive power without any external supervision often lack clear content and are, thus, toothless. Second, judicial involvement contributes to the formation of transparent, detailed, and stable legal standards that more effectively limit executive discretion. Such legal standards provide guidance to decisionmakers, constrain their power, and legitimize uses of force that are carried out in accordance with their requirements. Executive (civilian and military) lawyers are more independent and powerful in urging caution on policymakers when judicial review is likely. Thus, there is a symbiotic relationship between the application of judicial scrutiny and the resilience of internal mechanisms for legal review within the executive branch. Finally, the efficacy of the legislative process as a meaningful restraint on executive action is found wanting. Legislative capacities and motivation to police executive conduct in counterterrorism operations is significantly limited by structural and collective actions problems.

This article proceeds in three parts. Part I identifies the unique challenges of institutional design presented by counterterrorism targeting. Part II examines the American, British, and Israeli models for regulating counterterrorism targeting. Part III presents the key insights produced by this comparative experiment and concludes by discussing possible reforms.

\section{FRAMING THE PROBLEM: THE UNIQUENESS OF COUNTERTERRORISM TARGETING}

Thinking about the regulation of targeted killing from the war powers debate perspective creates a number of problems. The war powers debate is rooted in the traditional state-to-state war model, with its accompanying assumptions about the overarching framework of, the actors involved in, and the risks posed by war. From a functionalist perspective, these assumptions typically serve as key justifications for executive dominance over war-related issues. ${ }^{25}$

\footnotetext{
25 See, e.g., The Federalist No. 70, at 358 (Alexander Hamilton) (Clinton Rossiter ed., 1961). (maintaining that in the prosecution of war "the energy of [a unitary] Executive is the bulwark of the national security." See also Yoo \& Nzelibe, supra note 16, at 2512; POSNER \& VERMEULE, supra note 16, at 29-31.
} 
But when we shift from the traditional war context to counterterrorism, some of those assumptions become inapposite; they can no longer serve as valid premises for analysis of the roles of different governmental actors, and thus the case for executive dominance is weakened. In this part, I identify three critical assumptions of the war-powers debate and suggest why each is weakened or obviated entirely by the distinctive features of counterterrorism.

\section{A. War is distinguishable from peace?}

The first assumption of the traditional war powers debate is that a state of war is readily distinguishable from a state of peace. Wars between nation states are characterized by clear boundaries. Spatially, the war zone encompasses the territories of belligerent states, and the territories of neutral states are held inviolable. ${ }^{26}$ Temporally, 'wartime' has an identifiable starting point, sometimes marked by a declaration of war, and a termination point, usually in the form of an armistice or peace treaty. ${ }^{27}$ Conceptually, combatants are distinguished from civilians and that conceptual distinction is borne out visually; combatants are identifiable by their uniforms or other distinctive signs. $^{28}$ In the aggregate, these features marking the geographical and temporal borders of war and distinguishing between active combatants and protected persons, function as safeguards against uncontrolled accretion of executive power.

Armed conflicts against terrorist organizations lack those clear limiting features of traditional war. Hostilities frequently occur beyond traditional battlefields, including in states not directly implicated in the war. ${ }^{29}$ As the

${ }^{26}$ Hague Convention (V) Respecting the Rights and Duties of Neutral Powers and Persons in Case of War on Land, Oct. 18, 1907, 36 Stat. 2310, T.S. No. 540, art. I. See also Laurie Blank, Targeted Strikes: The Consequences of Blurring the Armed Conflict and Self-Defense Fustifications, 38 WiLliam MitcheLl L. REv., 1655, 1678 (2012) (“[w] hen two or more states are fighting and certain other states remain neutral, the line between the two forms the divider between the application of the laws of war and the law of neutrality").

${ }^{27}$ Accordingly, IHL provides that prisoners of war may be held captive until "the cessation of active hostilities." Geneva Convention (III) Relative to the Treatment of

Prisoners of War art. 127, Aug. 12, 1949, 75 U.N.T.S., 135, art. 118 (hereinafter, GC III). See also Rosa E. Brooks, War Everywhere: Rights, National Security Lawe, and the Law of Armed Conflict in the Age of Terror, 153 U. PA. L. REv. 675 (2005); MARY L. DudZIAK, WAR-TIME: AN IDEA, ITS HISTORY, ITS CONSEQUENCES 4 (2012) (" [w] artime becomes a justification for a rule of law that bends in favor of the security of the state. Traditionally, this distortion has been tolerated because wars end").

${ }^{28}$ GC III, supra note 26, art. 4 .

29 See, e.g., 2018 Presidential Report on National Security, supra note 9, at 1-3 (specifying eight different countries in which U.S. armed forces are currently deployed in various combat and supporting roles). 
prolonged wars in Afghanistan and Iraq demonstrate, it is often impossible to foresee when and under what circumstances hostilities will end ${ }^{30}$ and, indeed, to know if had ended. ${ }^{31}$ Finally, fulfillment of the obligation to distinguish between combatants and non-combatants is made far more difficult. As terrorist activity typically is conducted clandestinely, terrorists tend to avoid wearing uniforms or other distinctive signs. That problem is conflated by the fact that identifying an organization as a hostile force and establishing membership of the suspect in that organization "grows more difficult as organizations, such as Al-Qaeda, become a network of small dispersed cells, or even individuals." 32 As a legal matter, it is far from clear what constitute "membership" in such hostile armed groups. ${ }^{33}$

These unique features of counterterrorism mean that the constraints on executive power embedded in traditional wars - the identifiability of states of war and peace (in space and time) and the clear distinction between combatants and civilians do not operate in the counterterrorism context. Hence, the features of the war paradigm that may justify affording the executive exceptional flexibility and control in traditional wars do not necessarily justify affording such latitude to the executive in conducting counterterrorism missions. To be sure, there are reasons, including new reasons specific to modern terrorism, for providing executives with the powers necessary to suppress contemporary threats quickly and effectively. Indeed, the proliferation of technologies - from harmful cyber capabilities to armed drones - renders states more vulnerable than ever before in many ways. It is, thus, crucial that those who we hold accountable for our security be allowed to take the measures required to protect public safety. We cannot, however, assume that the same shift in the balance of domestic legal authority that characterized past wars is justified in the current context.

30 See Curtis A. Bradley \& Jack L. Goldsmith, Congressional Authorization and the War on Terrorism, 118 HARV. L. REV. 2047, 2049 (2005) ("[i]t is unclear how to conceptualize the defeat of terrorist organizations, and thus unclear how to conceptualize the end of the conflict"). The hostilities between Israel and Hamas, the de facto sovereign in the Gaza strip are another example. In 2000, Israel launched a massive military campaign against Hamas and other armed militant groups. Even though intense hostilities have decreased significantly, especially since 2014, the Supreme Court of Israel recently held that the state of armed conflict has not ceased. See, HCJ 3003/18 Yesh Din vs. The Chief of the General Staff, $₫ 38$ (May 24, 2018) (Isr.).

31 See Al-Alwi v. Trump, 901 F.3d 294, 297 (D.C. Cir. 2018), cert. denied, 139 S. Ct. 1893 (2019) (rejecting a habeas petition alleging that the war in Afghanistan ended).

32 Blum \& Heymann, supra note 14, at 147.

33 See infra in Section I.C. 
B. International law imposes constraints on executive power?

The second assumption underlying war powers-based debates is that international law regulates and - at least to some degree - constrains the executive's war-making authority. ${ }^{34}$ As Professor Rebecca Ingber noted, "few attempt to assert wholly uncabined presidential prerogative. In seeking a limiting principle, lawyers within the executive branch and courts at times point to international law as providing that limitation; they often do so on the view that it provides real and appropriate limits on government action." 35

Whether international law ever can genuinely and effectively limit domesticlaw war authority is contestable. The literature suggests that international law has at times been used by executives as a means to extend their domestic legal authority, sometimes even to overcome domestic law prohibitions. ${ }^{36}$ In her critique of this practice, Professor Ingber showed that the greater the indeterminacies of international law and the greater the executive's authority to interpret its meaning, the weaker is the constraining influence of international law on executive action. ${ }^{37}$ This is because (1) legal ambiguity gives the interpreter wide latitude to narrowly construe restrictions on state power while drawing on international law's grants of authority to compensate for lack of clear domestic law authority; and (2) interpretive deference from other political actors signals to the Executive that even controversial assertions of authority will not be challenged.

Despite years of state practice and extensive commentary, the international law governing counterterrorism targeting remains highly disputed. International law therefore poses little constraint on the executive's development and implementation of counterterrorism targeting policies. While an in-depth discussion of all of the relevant legal indeterminacies is

34 This assertion has been referenced specifically by the U.S. government to justify the use of targeted killing against American citizens. See Harold H. Koh, Legal Adviser, U.S. Dep't of State, Speech at the Annual Meeting of the American Society of International Law: The Obama Administration and International Law (Mar. 25, 2010) https://20092017.state.gov/s/1/releases/remarks/139119.htm (claiming that U.S. drone policy is consistent with the applicable international law and thus should not be viewed as violating the domestic law ban on assassinations).

${ }^{35}$ Rebecca Ingber, International Law Constraints as Executive Power, 57 HARV. INT'L L. J. 49, 60 (2016).

36 See id., at 61-76 (describing multiple mechanisms through which the Executive uses international to enhance its domestic legal authority); Curtis A. Bradley \& Jean Galbraith, Presidential War Powers as an Interactive Dynamic: International Law, Domestic Law, and Practice-Based Legal Change, 91 NYU L. REV. 689 (2016) (documenting a presidential practice to invoke international law to expand executive domestic war powers vis-à-vis Congress);

37 Ingber, supra note 35. 
beyond the scope of this article, a few key points will illustrate the level of legal ambiguity surrounding this topic.

Consider first the international law on the use of force (jus ad bellum), which prohibits extraterritorial force unless conducted in self-defense or under the auspices of the U.N. Security Council. ${ }^{38}$ A decade ago, the question whether the right to use force in self-defense applies to threats emanating from nonstate actors such as terrorist organizations generated conflicting views. ${ }^{39}$ Although the consensus in international law now gravitates toward acknowledging such right, the contours of the law in this area remain uncertain. ${ }^{40}$ This is especially true concerning preventive uses of force. In many counterterrorism situations, it may be difficult to argue that the threat is imminent and concrete enough to justify preventive force based on a traditional understanding of those terms. ${ }^{41}$ But governments practicing targeted killing have often adopted a permissive interpretation of the terms purportedly necessary and appropriate to the circumstances of transnational terrorism, ${ }^{42}$ or have argued that the targeting of individuals not belonging to

38 U.N. Charter, art. 2, ๆ. 4, 51.

${ }^{39}$ Compare Legal Consequences of the Construction of a Wall in the Occupied Palestinian Territory, Advisory Opinion, 2004 I.C.J. 136, 139 (July 9) ("Article 51 of the Charter thus recognizes the existence of an inherent right of self-defence in the case of armed attack by one State against another State”) with S.C. Res. 1368, ๆ 3, U.N. Doc. S/RES/1368 (Sept. 12, 2001) (passed in response to the 9/11 attacks; "[r]ecognizing the inherent right of individual or collective self-defence in accordance with the Charter"). See also Monica Hakimi, Defensive Force against Non-State Actors: The State of Play, 1, 4-16 91 INT'L. L. STUD. (2015) (analyzing the main sources of both views).

40 See, e.g., Hakimi, supra note 39, at 5, 19 (maintaining that the restrictive view of the right of self-defense had become "increasingly out of touch with the operational practice"; yet, recognizing a "gap between the norms that are widely articulated as law and the ones that reflect the operational practice"); Daniel Bethlehem, Self-Defense Against an Imminent or Actual Armed Attack by Nonstate Actors, 106 AM. J. INT'L. L. 770, 774 (2012) (claiming that "[i]t is by now reasonably clear and accepted that states have a right of self-defense against attacks by nonstate actor;" lamenting the "paucity of considered and authoritative guidance on the parameters and application of that right"); NOAM LUBELL, EXTRATERRITORIAL UsE OF FORCE AGAINST NON-STATE ACTORS, 43-63 (2010) (analyzing the parameters applicable in determining the scope of the tight of self-defense against non-state actors).

41 The language used in the famous exchange of letters between U.S. Secretary of State Daniel Webster and Lord Ashburton, the British envoy to the U. S., which became the authoritative standard in international law for anticipatory self-defense, was that the necessity of self-defense must be "instant, overwhelming, leaving no choice of means, and no moment for deliberation." Letters between U.S. Secretary of State Daniel Webster and U.K. Foreign Secretary Lord Ashburton, encl. 2 (July 27, 1842), http://avalon.law.yale.edu/19th_century/br-1842d.asp\#web2. For a comprehensive historical account see Craig ForGese, Destroying the Caroline: The Frontier RaID THAT RESHAPED THE Right TO WAR (2018).

42 See U.S. Dep't of Justice, White Paper, supra note 7, at *8 (arguing that a person may be viewed as posing an imminent threat if he "personally and continually involved in 
identified "enemy forces" in territories far from "hot" battlefields is undertaken as a part of - or at least in connection with--a preexisting armed conflict (hence, obviating the need to establish anew the jus ad bellum prerequisites). ${ }^{43}$ While these interpretive theories have been criticized as excessively permissive, they remain available and are invoked regularly as a basis for action. ${ }^{44}$

The U.S. has taken the position that targeted attacks in foreign territory without the consent of the host state are lawful if the host state is unable or unwilling to suppress a terrorist threat emanating from its territory. ${ }^{45}$ While state practice indicates some acceptance of this position, ${ }^{46}$ the 'unable-orunwilling' test in its current form lacks agreed-upon factors and, as a result, does not impose real constraints on a state's use of force. ${ }^{47}$

planning terrorist attacks," or has recently been involved in such activities and "there is no evidence suggesting that he has renounced or abandoned them"); JCHR Drones Report, supra note 18, at 93.33 ("The Government has made clear, in the course of our inquiry, that it favours a more flexible approach to the meaning of "imminence", to include an ongoing threat of a terrorist attack from an identified individual who has both the intent and the capability to carry out such an attack without notice")

43 See 2016 Presidential Report on National Security, supra note 9, at 15-18 ("in armed conflicts with non-State actors that are prone to shifting operations from country to country, the United States does not view its ability to use military force against a non-State actor with which it is engaged in an ongoing armed conflict as limited to "hot" battlefields."); JCHR Drones Report, supra note 18, at 9 1 2.9-2.11 (describing the U.K. government's position according to which, a targeted strike in Syria was carried out as part of the armed conflict against ISIS in Iraq).

44 See, e.g., Special Rapporteur on the Promotion and Protection of Human Rights and Fundamental Freedoms While Countering Terrorism, ๆ57-58, A/68/389 (Sep. 18, 2013). Note, however, that the invocation of the imminence standard in counterterrorism missions further raises policy concerns, including for excessively constraining state power. See generally Luke Hartig, Pluses and Minuses of the Imminence Standard in Counterterrorism Strikes, JusT SECURITY (Oct. 20, 2017) https://www.justsecurity.org/46135/pluses-minuses-imminencestnd-ct-strikes.

${ }^{45}$ Letter from the Permanent Representative of the United States of America to the

United Nations addressed to the Secretary-General (Sep. 23, 2014) http://www.securitycouncilreport.org/atf/cf/\%7B65BFCF9B-6D27-4E9C-8CD3CF6E4FF96FF9\%7D/s_2014_695.pdf. See also Jack Goldsmith, The Contributions of the Obama Administration to the Practice and Theory of International Law, 57 HARV. INT'L L. J. 1, 8 (2016).

46 See Elena Chachko \& Ashley Deeks, Who Is on Board with "Unwilling or Unable"?, LAWFARE (Oct. 10, 2016, 1:55 PM), https://www.lawfareblog.com/who-board-unwillingor-unable; European Council On Foreign Relations, Europe's New Counter-Terror War (by Anthony Dworkin), 12 (2016) https://www.ecfr.eu/page/-/ECFR192__EUROPES_NEW_COUNTER-TERROR_WARS_FINAL.pdf, (describing a shift in the position of European countries towards greater acceptance of the unable or unwilling standard).

47 Ashley S. Deeks, "Unwilling or Unable": Toward a Normative Framework for Extraterritorial Self-Defense, 52 VA.J. InT'L L. 483 (2012). See also, Bethlehem, supra note 40, at 776; LuBELL, 
Similar problems arise in the application of the law on the conduct of hostilities (jus in bello, or IHL) to counterterrorism. There is no consensus regarding fundamental topics in IHL such as "who may properly be targetable within the nonstate-actor continuum of those planning, threatening, perpetrating, and providing material support essential to an armed attack;" 48 whether an attempt must be made to address the threat through non-lethal means before lethal force is employed, ${ }^{49}$ and other such questions. ${ }^{50}$ These persisting uncertainties have led commentators to question whether the traditional dichotomy between the legal regimes applicable in war and in peace represents a workable paradigm for regulating the use of force in counterterrorism..$^{51}$

Notably, the problem of adapting to change is not new for international law. As famously conceptualized by H.L.A. Hart, international law is an immature legal system that lacks the crucial "secondary rules" that establish the content

supra note 40, at 37-42; Olivier Corten, The "Unwilling or Unable" Test: Has It Been, and Could It Be, Accepted?, 29 LeIDen J. InT'L L. 777 (2016); Chatham House, Principles of International Law on the Use of Force by States in Self-Defence, at 11 (Oct. 1, 2005) (by Elizabeth Wilmshurst) https://www.chathamhouse.org/publications/papers/view/108106.

48 Bethlehem, supra note 40, at 775.

49 Compare e.g., Alexander K.A. Greenawalt, Targeted Capture, 59 HARv. InT’L L. J. 1 (2018) (asserting a legal duty under IHL to employ less lethal means than killing when feasible) with Jens David Ohlin, The Duty to Capture, 97 MInN. L. REv. 1268 (2013) (denying the existence of a duty to attempt capture before resorting to lethal force under IHL).

50 One example is the controversy surrounding the IHL rule providing that civilians will be immune from attacks "unless and for such time as they take a direct part in hostilities" (codified under Protocol Additional to the Geneva Conventions of 12 August 1949, and Relating to the Protection of Victims of International Armed Conflicts (Protocol I), adopted June 8, 1977, art. 51(3)). Critics have debated the circumstances for when civilians implicated in terrorism lose their civilian immunity and whether the initial classification of members of terrorist groups as 'civilians' (rather than 'members of armed groups' who may qualify essentially as combatants) is correct. See, e.g., The International Committee of the RED Cross, Interpretive Guidance on the Notions of Direct Participation under International Humanitarian Law (by Nils Melzer) (2009); Kenneth Watkin, Opportunity Lost: Organized Armed Groups and the ICRG Direct Participation in Hostilities Interpretive Guidance, 42 NYUJ. InT'L L. POL. 641 (2010); W. Hays Parks, Part IX of the ICRC "Direct Participation in Hostilities" Study: No Mandate, No Expertise, and Legally Incorrect, 42 N.Y.U.J. INTL. L. \& POL. 769 (2010); Michael N. Schmitt, Deconstructing Direct Participation in Hostilities: The Constitutive Elements, 42 NYU J. INT'L L. POL. 697 (2010); Bill Boothby, And for Such Time as: The Time Dimension to Direct Participation in Hostilities, 42 NYUJ. INT'L L. POL. 741 (2010).

51 See, e.g., Hakimi, supra note 14, at 1365 (contending that invoking what she refers as "the domain method" for counterterrorism is "practically unworkable and theoretically dubious"); Dworkin, supra note 46, at 14 (arguing that "the use of force purely to prevent an organization from conducting terrorist attacks should be distinguished from traditional uses of military force). 
and meaning of the law. ${ }^{52}$ The absence of 'world' legislative and judicial institutions to resolve disputes authoritatively allows strong states a great deal of room to maneuver, especially when there are reasonable disagreements about how the law applies to new circumstances. ${ }^{53}$ There is little to inhibit an executive relying on its broad war-powers authority from taking action and then finding or devising an international law theory to support it. ${ }^{54}$

\section{Status-based targeting?}

The third assumption underlying traditional war powers debates concerns the individual enemy combatant. In wars between states, the mere allegiance of an individual to the armed forces of the enemy state was sufficient to make him a lawful target. There was no need to evaluate his immediate conduct or future intentions. In contrast, decisions to kill or capture suspected terrorists are made de facto on the basis of individual conduct as a predictor of future dangerousness. ${ }^{55}$ The conduct deemed relevant in this regard has included both acts unlawful in themselves and broader links or associations with a recognized enemy organization. ${ }^{56}$ The shift is thus made from "categorical, group-based judgments that turned on status" to "a world that implicitly or explicitly requires the individuation of enemy responsibility." 57 Put differently, each targeted killing requires a prior individualized determination of whether the available evidence justifies the killing of the particular individual in question. This individualized process entails various problems unaccounted for in traditional battlefield targeting, where a simple visual identification is assumed to provide sufficient indication that the target is lawful. Here, in contrast, evidence are collected and assessed in a process

52 H.L.A. HART, The CONCEPT OF LAW, 92-98, 213-237 (2nd ed., 1994).

53 The problem is further aggravated by the fact that traditional IHL enforcement mechanisms such as reprisal and reciprocity which, at least in theory, deter states from breaking the law, are inapplicable in conflicts that involve state versus non-state actors. See generally Sean Watts, Reciprocity and the laws of war, 50 HARV. INT'L L. J. 365, 365-70 (2009); Shane Darcy, The Evolution of the Law of Belligerent Reprisals, 175 MIL. L. REV. 184 (2003).

${ }^{54}$ Derek Jinks \& Neal Kumar Katyal, Disregarding Foreign Relations Law, 116 YALE L.J. 1230, 1244-45 (2007) ("any practical advantages of judicial deference are substantially offset by the costs of assigning robust interpretive authority to the very agency that is regulated by the [international legal] regime").

55 See, e.g., White House Memorandum, Presidential Policy Guidance: Procedures for Approving Direct Action against Terrorist Targets Located outside the United States and Areas of Active Hostilities (May 22, 2013) (hereinafter, $P P G$ ).

56 See infra Part II.

57 Samuel Issacharoff \& Richard H. Pildes, Targeted Warfare: Individuating Enemy Responsibility, 88 N.Y.U. L. REV. 1521, 1522-23 (2013). See also Gabriella Blum, The Individualization of War: From War to Policing in the Regulation of Armed Conflicts, in LAW AND WAR (Austin Sarat et. al. eds., 2014). 
more akin to a criminal investigation or trial. Process failures resulting from error or bias are significantly more likely to occur in these circumstances.

In sum, the regulation of targeted killing entails problems not posed by traditional war: prolonged and spatially-diffuse hostilities, indeterminate international legal terrain, and novel target identification challenges. In light of these significant differences between traditional wars and counterterrorism, we cannot hope to rely upon assumptions drawn from the former context to render accurate conclusions with regard to the latter. The next Part compares three institutional structures designed to address these distinctive problems of counterterrorism.

\section{Regulating TARgETED KILLING IN THE U.S, THE U.K., AND ISRAEL}

This Part examines three different approaches for tackling those unique institutional challenges of counterterrorism targeting. Sections A, B, and C below analyze the American, British and Israeli models. Each section, after a brief historical overview of the general distribution of powers under the foreign relations law of the state in question, explains the legal and geopolitical background underlying that state's targeting policy, describes the state's counterterrorism targeting decision-making framework, and explores what internal/constitutional accountability mechanisms each state applies. In evaluating each model, this Part assumes that an effective regulatory framework must achieve three objectives: facilitating accurate decisionmaking, promoting accountability, and preventing illegality.

My goal in this Part is merely descriptive. I will show that institutional choice - the assignment of authority and responsibility to different government actors - influences in patterned and relatively predictable ways how states construct their targeting schemes, interpret the governing international and domestic law, and hold their officials legally and politically accountable. A normative assessment of the main findings will follow in Part III.

\section{A. The United States: executive primacy}

In 1999, Professor Curtis Bradley coined the term 'foreign affairs exceptionalism' to characterize the distinctive treatment of foreign affairs 
powers in American politics and law. ${ }^{58}$ The realm of foreign affairs is 'exceptional' in the sense that, historically, U.S. Presidents have generally exerted greater influence, and been subjected to fewer constitutional checks, in the foreign policy realm than in other areas. ${ }^{59}$ The prevalence of statutes granting broad delegations of authority (and discretion) to the executive, the inefficacy of the few statutes that have sought to limit executive power in this area, and the frequent application of judicial doctrines limiting adjudication of foreign affairs disputes (and affording broad deference in those cases that are adjudicated) have set foreign affairs apart from domestic affairs and fostered executive dominance over foreign policymaking. ${ }^{60}$ For the last two decades, empirical and normative debates about whether - and howforeign affairs matters should be considered and treated as exceptional have been the bread and butter of American scholarship in this field. Despite several studies which have suggested that U.S. foreign relations law has been going through a process of 'normalization' in federal courts, ${ }^{61}$ recent Supreme Court decisions indicate that the field as a whole is still largely characterized by executive primacy. ${ }^{62}$

${ }^{58}$ Curtis A. Bradley, A New American Foreign Affairs Law?, 70 U. ColO. L. REv. 1089, 1096 (1999) (defining exceptionalism as "the view that the federal government's foreign affairs powers are subject to a different, and generally more relaxed, set of constitutional restraints than those that govern its domestic powers").

59 An even more radical view of foreign affairs authority as an extraconstitutional presidential prerogative was adopted by the U.S. Supreme Court during the 1930-40s but is unlikely to be endorsed today. See Michael D. Ramsey, The Myth of Extraconstitutional Foreign Affairs Power, 42 WM. \& MARY L. REv. 379 (2000); Robert D. Sloane, The Scope of Executive Power in the Twenty-First Century: An Introduction, 88 B.U. L. REV. 341,349 (2008).

60 See, e.g., Terry M. Moe \& William G. Howell, The Presidential Power of Unilateral Action, 15J. L. ECON. \& ORG. 132, 141-42 (1999) (demonstrating that broad delegations of authority are more likely with respect to foreign relations statutes); ERIC POSNER \& ADRIAN Vermeule, The Executive Unbound: After the Madisonian Republic 85-100 (2008) (analyzing the failure of statutes to constrain presidential power, specifically in the areas of "warmaking, foreign policy, and emergencies").

61 See Ganesh Sitaraman \& Ingrid Wuerth, The Normalization of Foreign Relations Law, 128 HARV. L. REV. 1897 (2015) (providing a comprehensive historical analysis of foreign affairs normalization); Harlan G. Cohen, The Death of Deference and the Domestication of Treaty Law, 2015 BYU L. REV. 1467 (2016) (identifying a Supreme Court trend to domesticate "the questions presented in treaty cases" as a way to lower deference in foreign affairs law); Aziz Z. Huq, Against National Security Exceptionalism, 2009 SuP. CT. REV. 225, 226 (arguing that analysis of post-9/11 jurisprudence suggests that "there is nothing sui generis about the behavior of courts in the domain of national security"). But see Curtis A. Bradley, Foreign Relations Law and the Purported Shift Away from Exceptionalism, 128 HARV. L. REV. FORUM 294 (2015) (questioning the empirical basis of the normalization thesis); Carlos M. Vazquez, The Abiding Exceptionalism of Foreign Relations Doctrine, 128 HARV. L. REv. FORUM 305 (2015) (same).

62 See, Zivotofsky v. Kerry, 135 S. Ct. 2076 (2015) (recognizing exclusive presidential authority to recognize foreign nations); Trump v. Hawaii, 138 S. Ct. 2392 (2018) (upholding 
Counterterrorism targeting is one area where exceptionalism is still at its peak. Each of the recent five U.S. administrations has nurtured the perception that as a matter of law, counterterrorism targeting is akin to conventional military targeting and, hence, should be subject to no special legal limits or institutional safeguards. In this section, I trace the historical evolution of counterterrorism targeting in the U.S. and demonstrate that this largely unchallenged conceptualization has all but foreclosed judicial review and limited Congress' role in this field. In lieu of constitutional checks and balances, the U.S. model relies on a "separation of powers" internal to the executive, featuring elaborate intra-agency and inter-agency decision-making procedures, as described and analyzed in sub-section 2 below.

\section{The historical evolution of executive unilateralism over targeting}

Every U.S. President since Bill Clinton has authorized overt targeted killing operations; indeed, each has made greater use of this tactic than his predecessor. Every presidential assertion of authority that went unchallenged by Congress and the courts has enabled, perhaps induced, an even broader assertion of authority by the next president, ratcheting up the unilateral power of the Executive to resort to targeting.

In 1998, in the wake of attacks on the U.S. embassies in Kenya and Tanzania, President Bill Clinton authorized targeted cruise missile attacks, in Afghanistan and Sudan, against al-Qaeda leader Osama bin-Laden. The attacks pounded al-Qaeda compounds in several locations, but bin-Laden survived. ${ }^{63}$ Reporting the military action to Congressional leaders, President Clinton stated that he directed the strikes "pursuant to my constitutional authority to conduct U.S. foreign relations and as Commander in Chief and Chief Executive." 64 He further asserted that the attempted targeted killing was legal under international law, noting that the strikes were a necessary and proportionate response, "intended to prevent and deter additional attacks by a clearly identified terrorist threat." 65 Clinton's statements implicitly relied upon two novel and controversial legal propositions: that the president enjoys independent constitutional authority to use lethal force overseas to prevent

executive policy restricting entry into the U.S. by nationals from a number of predominantly Muslim countries).

63 See Nat. Comm. on Terrorist Attacks upon the United States, The 9/11 Comm. Rep., 108-43 (2004), https://www.9-1 1commission.gov/report/911Report.pdf.

64 President William J. Clinton, Letter to Congressional Leaders Reporting on Military Action Against Terrorist Sites in Afghanistan and Sudan (Aug. 21, 1998), https://www.gpo.gov/fdsys/pkg/PPP-1998-book2/html/PPP-1998-book2-docpg1464.htm.

$65 i d$. 
terrorism, and that states enjoy a right, under international law, to use force in self-defense against threats emanating from non-state actors. ${ }^{66}$ The first claim was especially significant as it lacked any principled limitation on the presidential power claimed: as articulated, every use of force can easily be deemed by Presidents to emanate from the Commander in Chief power. The second claim illustrates how expansive reading of international law's grants of authority is invoked to enhance the President's domestic law authority. Notwithstanding the significance of these claims, Congress acquiesced, as members from both sides of the aisle voiced their support of the strikes. ${ }^{67}$ The courts, for their part, dismissed as non-justiciable damage suits arising from the attacks, even though it appeared that private property was destroyed due to the erroneous conclusion that the property - a pharmaceutical plant - was involved in the production of chemical weapons. ${ }^{68}$ The framing of the missile attacks as an exercise of the President's war powers under the Constitution was central to the courts' view that the law suits presented nonjusticiable political questions. ${ }^{69}$ None of the opinions considered the legal questions arising from the President's novel legal claims or the propriety of having framed the issues involved as arising under the war powers.

After the terrorist attacks of 9/11, Congress supplemented the purported constitutional authority to target terrorists claimed by Clinton with a statutory Authorization to use Military Force (AUMF) "against those nations, organizations, or persons [the President] determines planned, authorized, committed, or aided the terrorist attacks."70 The use of lethal force as a counterterrorism measure has been understood thereafter - by Presidents Bush, Obama, and Trump - to have both statutory and constitutional foundations (both of which they have interpreted expansively). ${ }^{71}$ In 2001,

66 Supra note 38.

67 A few notable outliers were critical of the strikes. Their concern, however, was not based on principle but rather on questions regarding possible connection between the timing of the strikes and the Lewinski scandal. See CNN, Most Lawmakers Support Clinton's Military Strikes (Aug. 20, 1998) http://www.cnn.com/ALLPOLITICS/1998/08/20/strike.react/.

68 El-Shifa Pharm. Industries Co. v. U.S., 378 F.3d 1346 (Fed. Cir. 2004); El-Shifa Pharm. Industries Co. v. U.S., 607 F.3d 836 (D.C. Cir. 2010).

69 See El-Shifa Pharm. Industries Co., 378 F.3d, at 1365 ("the Constitution envisions that the political branches, directly accountable to the People, will adopt and promulgate measures designed to ensure that the President makes the right decision when, pursuant to his role as Commander-in-Chief, he orders the military to destroy private property in the course of exercising his power to wage war" (emphasis added)).

70 Pub. L. No. 107-40, 115 Stat. 224 (2001).

${ }^{71}$ As recently emphasized by the Trump administration, the Authorization for Use of Military Force Against Iraq (Pub. L. No. 107-243, 116 Stat. 1498 (2002)) is understood to provide additional authority to thwart "terrorist threats emanating from Iraq" and to take direct action against ISIS in Iraq or elsewhere. See 2018 Presidential Report on National Security, supra note 9 , at 3 . 
President Bush signed a Presidential Finding, authorizing the CIA covertly to kill or capture al-Qaeda members worldwide. ${ }^{72}$ Nevertheless, during most of the Bush era, targeted killings outside 'hot battlefields' were relatively uncommon and geographically restricted. ${ }^{73}$ President Obama, upon taking office, expanded counterterrorism targeting to additional theaters of operation and increased their overall frequency. ${ }^{74}$ Military and CIA personnel carried out targeted killings in states not implicated in the wars in Afghanistan and Iraq (such as Pakistan, Libya, Somalia, Iraq, and Yemen) ${ }^{75}$ against both aliens and U.S. citizens. ${ }^{76}$ President Trump has continued to rely on targeting as a key tactic of counterterrorism ${ }^{77}$ and, according to some estimates, escalated targeted strikes in multiple arenas in the Middle East and Africa. ${ }^{78}$

Since 2001, Congress has continued to appropriate funds for the 'war on terror.' The Executive, in turn, has relied on those appropriations to claim that Congress has endorsed its construction of the AUMF to cover the use of

72 See Robert Chesney, Military-Intelligence Convergence and the Law of the Title 10/Title 50 Debate, 5 J. Natl. SeG. L. Pol'y. 539, 562-63 (2012). See also, John Rizzo, Company Man: THIRTY YeARs OF CONTROVERSY AND CRISIS IN THE CIA 173-74 (2013)

73 Between 2004 and 2009, according to journalistic and non-governmental sources, President Bush authorized approximately 50 to 57 drone strikes, most of them in Pakistan. See, e.g., the Bureau of Investigative Journalism, Obama Covert Drone War in Numbers: Ten Times More Strikes than Bush (Jan. 17, 2017), https://www.thebureauinvestigates.com/stories/2017-01-17/obamas-covert-drone-war-innumbers-ten-times-more-strikes-than-bush.

${ }^{74}$ Between 2009 and 2016, the U.S. carried out 473 acknowledged targeted strikes that caused over 2,400 deaths in seven different countries, of which between 64 and 16 have been identified as civilians. See Office of the Director of National Intelligence, Summary of InFormation REgarding U.S. COUnTERTERrorism Strikes OUtSide Areas OF ACtive Hostilities (Jul. 1, 2016) (hereinafter, ODNI Report).

75 See, e.g., 2016 Presidential Report on National Security, supra note__, at 15-18.

76 See Obama May 2013 speech, supra note 7 ("when a U.S. citizen goes abroad to wage war against America and is actively plotting to kill U.S. citizens, and when neither the United States, nor our partners are in a position to capture him before he carries out a plot, his citizenship should no more serve as a shield").

77 See 2018 Presidential Report on National Security, supra note 9, at 1-3 (reporting counterterrorism operations in various countries).

78 See, New America, America's Counterterrorism Wars: Tracking the United States' drone strikes and other operations in Pakistan, Yemen, and Somalia, https://www.newamerica.org/in-depth/americas-counterterrorism-wars/ (last visited, May 24, 2019) (reporting a surge in strikes in Yemen and Somalia under President Trump); Dan de Luce \& Sean D. Naylor, The Drones Are Back, Foreign PoL'y (Mar. 26, 2018, 07:55 AM) https://foreignpolicy.com/2018/03/26/the-drones-are-back/ (reporting that the Trump Administration has resumed strikes in Pakistan against Taliban forces); Declan Walsh \& Eric Schmitt, U.S. Strikes Qaeda Target in Southern Libya, Expanding Shadow War There, N.Y. TIMES (Mar. 25, 2018) (reporting expansion of US strikes in Libya). https://www.nytimes.com/2018/03/25/world/middleeast/us-bombs-qaeda-libya.html. 
military force against ISIS and other organizations it deemed "associated forces." "79 As Professor Jack Goldsmith noted, "[t] he extension of the 2001 AUMF to reach the Islamic State marks a significant unilateral extension of the Forever War." Yet, as Congress has not contested such extensions, it may be plausibly argued that it has ratified the Executive's reading of the appropriations statutes and the AUMF. ${ }^{80}$ Even when a majority in Congress has seemed unsatisfied with the existing legal regime, no proposal to update the AUMFs has garnered enough support to pass new, sustaining legislation. ${ }^{81}$ As for the courts, several lawsuits were filed in connection with targeting decisions but all were dismissed on various grounds. ${ }^{82}$ The opinions stressed, inter alia, that courts have no part to play in this area, both because "judicially discoverable and manageable standards" for adjudication are lacking and because military decisions should be "in the hands of those who are best positioned and most politically accountable for making them."83

79 The administration, in turn, has relied on appropriations to claim that Congress has endorsed its construction of the AUMF to cover the use of military force against ISIS. See Defendant's Memorandum of Law in Support of Motion to Dismiss, at 2, Smith v. Obama, 217 F. Supp. 3d 283 (D.D.C. 2016) (No. 16-843), 2016 WL 7785731.

80 The National Defense Authorization Act of 2012 affirmed that the President's original mandate under the AUMF included the authority to detain individuals who were part of or substantially supported "associated forces" of al-Qaeda or Taliban. Though the provision does not apply directly to targeting, both Obama and Trump have uninhibitedly authorized the use of force against associated forces under the same rationale. National Defense Authorization Act for Fiscal Year 2012, Pub. L. No. 112-81, sec. 1021, 125 Stat.1298, 1562 (2011)

${ }^{81}$ Overall, Congress considered numerous proposals to update the AUMFs or limit the use of force in other arenas but was unable to pass new legislation. See, e.g., H.R.J. Res.125, 113th Cong. (2014); S.J. Res. 44, 113th Cong. (2014); S.J. Res. 26, 114 th Cong. (2015); S. Amdt., 871-1003, 113th Cong. (2014); Preventing Preemptive War in North Korea Act of 2017, S. Res. 2047, 115th Cong. (2017).

82 See Al-Aulaqi v. Obama, 727 F. Supp. 2d 1 (D.D.C. 2010) (dismissing constitutional and international law claims regarding the secret inclusion of a U.S. citizen in a government 'kill list,' based on political question and standing grounds); Al-Aulaqi v. Panetta, 35 F. Supp. 3d 56 (D.D.C. 2014) (dismissing a damages suit arising from the targeted killing of two U.S. citizens) Jaber v. U.S., 155 F. Supp. 3d 70 (D.D.C. 2016), aff'd sub nom. Jaber v. U.S., 861 F.3d 241 (D.C. Cir. 2017), cert. denied sub nom. Jaber v. U.S., 138 S. Ct. 480 (2017) (dismissing claims of extrajudicial torture and killing under the Torture Victim Protection Act). The two most recent opinions involved allegations by two journalists, brought under the Administrative Procedure Act, the Constitution, and several other statutes, that they were unlawfully put on a government 'kill list' and, as applied to one of them, targeted for lethal action. In Zaidan v. Trump, 317 F. Supp. 3d 8 (D.D.C. 2018) the government moved to dismiss on grounds of standing, political question, and failure to state a plausible claim for relief. The court granted the government motion in part but allowed the constitutional claim of one of the journalists, who is a U.S. citizen, to proceed. In Kareem v. Haspel, No. GV 17 581 (D.D.C. Sept. 24, 2019), the Court dismissed the remaining count pursuant to the government's invocation of the State Secret Privilege.

${ }^{83}$ Al-Aulaqi, 727 F. Supp. 2d, at 52. See also, Faber, 861 F.3d, at 247. 
Once again, the courts did not question the executive's 'war-powers' framing of the issues, and proceeded under the assumption that - notwithstanding the hard and novel legal issues implicated - wartime decisions concerning the use of force are unreviewable.

\section{Checks Internal to the Executive}

In the absence of specific Congressional or judicial guidance, internal executive rules and decision-making procedures have become the primary mechanisms for regulating counterterrorism targeting. Beginning in 2013, the government put in place formalized, multi-step procedures administered by multiple agencies for nominating and vetting specific targets for lethal action. The legal rationale underlying these procedures was developed in formal (and, sometimes, informal) opinions offered by attorneys in the Department of Justice' Office of Legal Counsel (OLC) and senior legal advisors in other agencies. ${ }^{84}$ Below, I describe the regulatory regime governing U.S. targeting operations and consider how it interacts with the three objectives noted above: accurate decision-making, accountability, and prevention of illegality.

U.S. targeting regime is built on two tiers: a legal tier, which lays out the legal boundaries - as understood by the administration - of the authority to use lethal force against suspected terrorists; and a policy tier, which establishes rules and principles further limiting agency discretion. ${ }^{85}$ As a matter of law, the President claims expansive constitutional, statutory (since 9/11), and international law powers to use force abroad for counterterrorism. As read by the all recent presidents, the Constitution empowers the President to use force without Congressional approval when doing so is (1) "necessary to advance American national interests abroad" and (2) "the anticipated hostilities would

84 The growing role of government lawyers in national security policymaking has received increased attention in legal literature since the commencement of the war on terror. See generally, Daphna Renan, The Law Presidents Make, 103 VA. L. REV. 805 (2017); Dawn E. Johnsen, Faithfully Executing the Laws: Internal Legal Constraints on Executive Power, 54 UCLA L. REV. 1559 (2007); Gillian E. Metzger, The Interdependent Relationship Between Internal and External Separation of Powers, 59 EMORY L.J. 423, 425 (2009); Jennifer N. Marrett, The National Security Council Legal Adviser: Crafting Legal Positions on Matters of War and Peace, 8 J. NAT'L SEC. L. \& PoL'Y 153, 167-174 (2015); Neomi Rao, Public Choice and International Law Compliance: The Executive Branch Is a "They," Not an "It", 96 MiN. L. REV. 194 (2011).

85 Notably, the very question of whether those limiting principles are properly designated as policy guidelines is controversial. International actors and many commentators argue that at least some of them should be understood as binding rules of law. See, e.g., Special Rapporteur on the Promotion and Protection of Human Rights and Fundamental Freedoms While Countering Terrorism, \57-58, A/68/389 (Sep. 18, 2013) Committee on Legal Affairs and Human Rights Parliamentary Assembly of the Council of Europe, Drones and Targeted Killings: the need to uphold human rights and international law $\$ 48$ (Mar. 16, 2015). 
not rise to the level of a war in the constitutional sense." 86 These legal criteria are vague and may be satisfied relatively easily. ${ }^{87}$ On the statutory level, the two recent administrations have construed the AUMFs to permit targeting of a broad range of entities and individuals; when new threats emerge, broad criteria are applied to include them within existing authorizations for the use of force. ${ }^{88}$

In interpreting international law, these administrations have framed U.S. targeting operations as an exercise of the inherent right to use force in individual or collective self-defense, either with the consent of the state where force is used or upon a determination that that state is unable or unwilling to suppress a terrorist threat emanating from its territory. ${ }^{89}$ The validity of the latter standard as a rule of international law, the criteria for finding a state unwilling or unable, and whether those criteria are met in a given case are matters for exclusively executive determination as a matter of fact and law. Evidence suggest that this standard is applied permissively. ${ }^{90}$

Against this permissive legal regime, in 2013, the Obama administration adopted additional rules and procedures to regulate actions outside 'hot battlefields' (or "areas of active hostilities," as termed by the administration). This policy framework, known as the Presidential Policy Guidance (PPG), featured high-level vetting requirements and substantive constraints on the resort to force in places where hostilities are less frequent and not as intense as on conventional battlefields. Essentially, the PPG allowed the use of force only against individuals who were deemed to constitute a continuing and imminent threat to U.S. persons, when capture was not feasible, and when the risk to civilians was minimal. ${ }^{91}$ The PPG system also featured close civilian control on the operational decision-making of the military and the CIA

86 April 2018 Airstrikes Against Syrian Chemical-Weapons Facilities, 42 Op. O.L.C. 1, at $* 5$ (2018).

87 See Curtis Bradley \& Jack Goldsmith, OLC's Meaningless 'National Interests' Test for the Legality of Presidential Uses of Force, LAWFARE (Jun. 5, 2018, 3:13PM), https://www.lawfareblog.com/olcs-meaningless-national-interests-test-legality-presidentialuses-force.

88 See 2016 Presidential Report on National Security, supra note 9, at 4.

${ }^{89}$ In addition, U.S. targeting practices both inside and outside areas of active hostilities are said to conform to IHL rules - particularly the rules of distinction, military necessity, precautions in attack and proportionality. See generally 2018 Presidential Report on National Security, supra note 9; 2016 Presidential Report on National Security, supra note 9.

${ }^{90}$ For example, Pakistan was deemed by the Obama administration unable or unwilling to arrest Osama Bin Laden without approaching its government and even though the two governments have cooperated in dozens other counterterrorism operations prior to the raid on Bin Laden's compound. See Charlie Savage, Power Wars: Inside Obama's Post 9/11 PRESIDENCY, 263-64 (2015).

912016 Presidential Report, supra note 9, at 24-26. 
through an interagency nomination and vetting system. After been cleared and legally reviewed within the nominating agency, every target had to be approved in three interagency forums: the National Security Staff (NSS), the National Security Council (NSG) Deputies Committee, and the NSC Principals Committee. ${ }^{92}$ Finally, if a consensus as to a particular target was not achieved or the target was a U.S. citizen, the case went directly to the President for final authorization. ${ }^{93}$

President Trump retained the concept of "areas of active hostilities" but replaced the PPG with a different set of rules known as Principles, Standards, and Procedures (PSP). ${ }^{94}$ The PSP has not been made public but reportedly provides the military and CIA greater authority to act without civilian oversight, relaxes the PPG's multi-layered vetting procedures, and eliminates the imminence requirement. ${ }^{95}$ President Trump further revoked the reporting requirements placed by President Obama regarding civilian and combatant casualties from targeted strikes. ${ }^{96}$

Part III will examine how these institutional features bear on the efficacy of the U.S. model. However, a few preliminary observations are in order. First, the targeted killing practice under this regulatory regime is more legally vetted than any other instance of use of military force in U.S. history and, arguably, worldwide. It can be plausibly argued that clearly illegal attacks are highly unlikely to be approved. Second, the legal arguments underlying this regime have never been reviewed, nor are they likely to be reviewed under this regime, by a neutral decision-maker. It is highly likely that the attorneys who drafted the legal opinions supporting these arguments knew that fact as they were developing their positions. Third, and relatedly, this two-tiered regime peculiarly discerns most of domestic and international law grants of authority

92 PPG, supra note 55, at 2-3. See also McNeal, supra note 14, at 702-29; Cora Currier, The Kill Chain, The InTERGEPT (Oct. 15, 2015, 2:57 PM). https://theintercept.com/dronepapers/the-kill-chain/.

93 SAVAGE, supra note 89, at 283.

94 See, Complaint for Injunctive Relief, at *4, American Civil Liberties Union v. Department of Defense, No. 1:17-GV-09972 (S.D.N.Y., Dec. 17, 2017) (a Freedom of Information Act suit seeking to advertise Trump administration rules governing the use of lethal force abroad). See also, Adriana E. Jones, Implications of Trump's New Drone Policy for Countries Assisting the U.S., Just SEGurity (Nov. 13, 2017), https://www.justsecurity.org/47011/implications-trumps-drone-policy-countries-assisting$\mathrm{u}-\mathrm{s} /$.

95 Charlie Savage \& Eric Schmitt, Trump Poised to Drop Some Limits on Drone Strikes and Commando Raids, New York Times (Sep. 21, 2017),

https://www.nytimes.com/2017/09/21/us/politics/trump-drone-strikes-commandoraids-rules.html.

96 Exec. Order 13,862 Revocation of Reporting Requirement, 84 Fed. Reg. 8789 (Mar. $6,2019)$. 
in exceptionally broad terms while articulating limitations narrowly or simply defining them as policy constraints. ${ }^{97}$

\section{B. Britain: legislative oversight}

The English legal system traditionally viewed the conduct of foreign affairs as an exclusive Royal prerogative. ${ }^{98}$ As late as in mid-20 $0^{\text {th }}$ Century, the external relations of the state were understood as acts of sovereignty, largely immune from domestic legal control by Parliament or the courts. ${ }^{99}$ But since the 1950s, and more so in the last two decades, Parliament has passed several constitutional reforms in which it sought to reign in on the executive in the foreign affairs domain. Two changes in particular have proved relevant to the effort to regulate the executive's targeting authority.

The first is the passage of the Human Rights Act (HRA) of 1998. ${ }^{100}$ The HRA incorporated the European Convention on Human Rights (ECHR) into British law and established a new constitutional scheme for safeguarding human rights in Britain, in which Parliament and the judiciary were charged

${ }^{97}$ For instance, all recent administrations have adopted a broader conception of what constitutes 'imminent threat' that triggers the right of self-defense (See 2016 Presidential Report, supra note 9, at 9). The rationale suggested for this deviation is that current threats are different from past threats in ways that renders the traditional reading obsolete (see Brennan, supra note 4 (contending that "the traditional conception of what constitutes an "imminent" attack should be broadened in light of the modern-day capabilities, techniques, and technological innovations of terrorist organizations")). However, this rationale can in theory sometimes work against the government. Take for example the end-of-activehostilities principle, which was originally meant to create an objective threshold for limiting wartime detention authority. It can plausibly be argued that the malleable nature of armed conflicts with terrorist organizations render this test unworkable. The government, needless to say, has never advanced such reading of the detention authority, and in fact opposed such argument in court proceedings. See Al-Alwi v. Trump, 901 F.3d 294 (D.C. Cir. 2018), cert. denied, 139 S. Ct. 1893 (2019)

98 See Campbell Mclachlan, Foreign Relations law 33-59 (2014) (excerpting and analyzing the writings of Locke, Blackstone, Lord Mansfield, and Dicey).

99 See, e.g., William Blackstone, Commentaries on the laWs Of England, 24550 (Book I, 1765, reprinted 1992); Albert V. DiCEy, InTRODUCTION TO THE STUDY OF THE LAW OF THE CONSTITUTION, 393-94 (5 $5^{\text {th }}$ Ed., reprint 2004). One salient example is that Parliament had no role in ratifying treaties. This has changed only with the passage of the Constitutional Reform and Governance Act 2010 c. 25 (U.K.), which gave the House of Commons a new power to block ratification. The English judiciary, for its part, has traditionally deferred to the government on foreign affairs by invoking various exclusionary doctrines, which recognized that acts of sovereignty by the Crown are not proper matters for adjudication. See McLachlan, supra note 98, at 51-53. See also F.A. MAnN, Foreign AFFAIRS IN ENGLISH COURTS, 18-22 (discussing 20 ${ }^{\text {th }}$ Century cases acknowledging the nonjusticiability of foreign affairs matters).

100 C. 42 (U.K). 
with concurrent responsibility to enforce and protect Convention rights. ${ }^{101}$ In this new scheme, when the exercise of foreign relations powers affected individual rights, executive supremacy was no longer the default. As will be shown in this section, legislators have sought to invoke the ECHR to constrain the executive's authority to target individuals outside hot battlefields.

The second is a recent acceptance of a constitutional convention (i.e., an unwritten constituttional custom), according to which, before armed forces are deployed abroad, the executive must allow Parliament to debate the matter, save in times of emergency. ${ }^{102}$ This convention has had an immediate impact: in 2013, a government bid to use force against the Assad regime in Syria was defeated in the House of Commons; ${ }^{103}$ a subsequent bid to use force against ISIS was limited to Iraq and did not apply to Syria, out of concern for a similar defeat if approval had been sought for a wider intervention. ${ }^{104}$

It was against this background that, in 2015, a British drone killed Reyaad Khan, a British citizen and ISIS operative in Syria. ${ }^{105}$ The strike - which by some views violated the ECHR and was at odds with the new constitutional convention (and, in particular, defied a specific expression of Parliaments's will concerning the use of force in Syria) immidiately caused a political and legal turmoil.

What transpired from that incident was a different model than the American for regulating the use of targeted killing - a model of legislative oversight. Sub-section 1 describes the efforts in Parliament to work with the executive on devising clear and transparent legal standards for using force in counterterroism operations and designing a workable accountability regime; Sub-section 2 describes the executive's response to these efforts. The analysis will demonstrate how a model that rely on non-binding legislative review and a mere hope of a constructive inter-branch dialogue about the scope of the executive's authority to use force fails to have any real impact or promote

101 The HRA model has been described as a "subtle compromise" between the principle of Parliamentary sovereignty and the principle of judicial supremacy. It provides that courts are required to interpret statutes, where reasonably possible, as compatible with the ECHR and, where it is not possible, higher courts may make a declaration of incompatibility. However, such declaration does not invalidate the statute - only the Parliament may amend or repeal it. See Janet L. Hiebert, Parliament and the Human Rights Act: can the FCHR help facilitate a culture of rights? 4 INT'L. J. CONST. L. 1, 10-23 (2006).

102 The Cabinet Office, The Cabinet Manual, I 5.38 (2011) [U.K.]. See also James Strong, Why Parliament Now Decides on War: Tracing the Growth of the Parliamentary Prerogative through Syria, Libya and Iraq, 17 BRIT. J. POL. \& INT'L REL. 604 (2015)

10329 Aug. 2013, PARL. Deb., H.C. (2013) 1556 [U.K.].

10426 Sep. 2014, PARL. DEB., H.C. (2014) 1255 [U.K.].

105 BBC News, Islamic State conflict: Two Britons killed in RAF Syria strike (Sep 7, 2015) http://www.bbc.com/news/uk-34178998. Two others were reported dead in the attack, including Ruhul Amin, also a British citizen and Khan's cousin. 
accountability. This conclusion, I will argue later on, is even more striking given that Britain's legal and political ethos rests on the idea that constitutionalism is first and foremoset observed by political-rather than judicial - institutions. The failure of the British model detailed in this section should give pause to anyone who believe in the idea that war and national security powers can effectively be policed by the legislative process.

\section{The Parliament's drone inquiries}

Days after the strike on Khan, then-Prime Minister (PM) David Cameron addressed Parliament, confirming that the strike implemented a new counterterrorism strategy whereby direct action would be taken against threats to the British people, regardless of where those threats emanated. ${ }^{106}$ $\mathrm{He}$ insisted that the strike was consistent with the newly accepted constitutional convention mandating Parliament's approval, because it "was not part of coalition military action against [ISIS] in Syria; it was a targeted strike to deal with a clear, credible and specific terrorist threat." 107 Cameron's statement did not provide additional information about the decision-making process or the legal basis of the new policy. It was also contradicted by statements of other government officials, who said that the strike was carried out as part of the collective self-defense effort against ISIS in Iraq, within the context of an existing armed conflict. ${ }^{108}$

These inconsistent statements attracted the scrutiny of two Parliamentary committees. The Joint Committee on Human Rights (JCHR) commenced a comprehensive inquiry into the legal basis and human rights implications arising from the use of lethal force against British citizens overseas; the Intelligence and Security Committee (ISC) sought to investigate the intelligence basis for the Khan's strike and other strikes against British citizens conducted by U.S. forces with British support. ${ }^{109}$

The FCHR Drone Report. - Before discussing the conclusions of the Drone inquiry, a primer on the JCHR is necessary to fully appreciate its role within Britian's new constitutional scheme. The JCHR was established in 2002 to help facilitate Parliament's responsibility to implement the ECHR. ${ }^{110}$ The Comiittee's mandate includes monitoring the compatibility of governmental bills with Convention rights, reviewing remedial orders in response to judicial

1067 Sep. 2015, PARL. DeB., H.C. (2015) 1 [U.K.].

$107 \mathrm{Id}$.

108 See JCHR Drones Report, supra note 18, at $\uparrow$ 2.8-2.15.

109 See ISC Report, supra note 18.

110 For a background on the creation of the Committee see, e.g., JOINT COMM. ON Human Rts., Twenty-ThiRd Report: The CommitTeE's Future Working Practices, Appendix 1: Francesca Klug, Report on the Working Practices of THEJCHR, tables 4-5, HL 239, HC 1575, 2006 [U.K.]. 
declarations of incompatibility, and conducting inquiries on matters related to human rights. ${ }^{111}$ Its inquiries are best described as a hybrid of political deliberation and a quasi-judicial process. The Committee consists of an equal number of elected members of Commons and unelected members of Lords, and has never been controlled by a majority of the governing party. ${ }^{112}$ The Committee is aided by a full-time legal adviser who, according to scholarly accounts, has a dominant role in shaping its legal views and curbing politicization of its decision-making. ${ }^{113}$ Its inquiries include review of written and oral evidence, ${ }^{114}$ which are regularly received from governmental and nongovernmental bodies, as well as from academics and legal experts. ${ }^{115}$ With all of these institutional features, a former member of the Committee described its review as analogous to the function performed by "courts in assessing claims of human rights violations." 116 Nevertheless, the Committee's conclusions are not legally binding. Its work is meant to induce ministers to give proper weight to human rights concerns and to inform Parliament of possible tensions between bills/executive policies and human rights obligations. ${ }^{117}$

The JCHR's inquiry into the policy and legal aspects of the strike against Khan sought to inform Parliament and the public about the decision-making process and its internal checks and to appraise the government's claimed legal basis for the use of force against terrorist threats. A Report containing the main findings of the inquiry and providing recommendations to Parliament and the government was published in April 2016. ${ }^{118}$

The Report indicates that the government was not entirely forthcoming about its legal positions with respect to some key issues surrounding the scope of its authority to use force for counterterrorism. ${ }^{119}$ The language of the Report, nonetheless, makes clear that the Committee's positions departed from the views of the government in several important respects. First, the

111 See the JCHR Remit, Standing Order 2002(2): Seleat Committees, Sec. 152B [U.K.] (hereinafter, $7 C H R$ Remit). For an overview of the Committee's work practices see Joint Comm. on Human Rts., Nineteenth Report: The Work of the Committee IN THE 2001-2005 PARLIAMENT, 2005, HL 112, HC 552, (U.K.) (hereinafter, fCHR working practices report).

112 See Hiebert, supra note 81, at 16.

113 Id., at 17-20.

114 JCHR Remit, supra note 111, Sec. 152B.

115 See David Feldman, The Impact of Human Rights on the UK Legislative Process, 25 STATUTE L. REV. 191, 113 (2004).

116 Hiebert, supra note 101, at 17 (quoting former JCHR member Lord Anthony Lester). 117 Joint Comm. on Human RTS., SeGOnd SPECIAL RePORT: IMPlementation of THE HuMAN Rights ACT 1998, 2001, HL 66-I, HC 332-I, [U.K]).

${ }^{118}$ JCHR Drones Report, supra note 18.

119 See, e.g., id., at 43,63-64. 
JCHR maintained that IHL is applicable only where a targeted strike is delivered within an armed conflict, a concept it believed must be geographically confined to a location where hostilities have met the required threshold of violence under international law. ${ }^{120}$ Second, departing from what appeared as the government's position, the Committee viewed Human Rights Law (HRL) as the controlling international legal regime for the use of force outside a geographically defined war zone. The Report states that, outside such war zone, a premeditated use of lethal force is permissible only when it is absolutely necessary "to avert an immediate threat of unlawful violence to other people and be strictly proportionate to that aim," 121 and loss of life must be followed by an effective independent investigation. ${ }^{122}$ Third, the Committee required the government to clarify its meaning of "armed attack" and "imminence", the two threshold conditions to permit the use of force, and noted that too flexible an interpretation "risks leading to an overbroad [targeted killing] policy." 123 Finally, the Committee was troubled by the lack of clear standards guiding when the government may assist targeted killings carried out by its allies outside countries with which the U.K. is at war. ${ }^{124}$ In particular, the Report noted the controversial legal position of the U.S. on the geographical scope of armed conflicts against non-state actors. Alluding its discontent with reports that the government provided support to U.S.-led operations, the Committee observed that complicity "in the internationally unlawful act of another state is itself unlawful under general international law."125

The Report further provided a brief description of the target nomination process as reported to the Committee by the government. It explained that targets are submitted by the intelligence agencies to the National Security Council. Subject to legal clearance by the Attorney General and final authorization by either the PM or the Defense Secretary, the Council may approve the target. ${ }^{126}$

In the Report's conclusion, the Committee asked the government to respond to a series of questions regarding the government's targeting policy, its legal basis, and the safeguards and accountability mechanisms that it entailed.

The ISC Drone Report. - A major theme in the ISC inquiry concerned the severe constraints that the government placed on the Committee's access to

\footnotetext{
$120 \mathrm{Id}$., at 48-49.

121 Id., at 53 .

122 Id.

$123 \mathrm{Id}$., at 47.

${ }^{124} \mathrm{Id}$., at 57-58.

$125 \mathrm{Id}$., at 58.

126 Id., at 61 .
} 
information. "The failure to provide what we consider to be relevant documents on an issue of such seriousness," the Report stated, was "profoundly disappointing: it has had a significant bearing on the conclusions we have reached." 127 Prior to the commencement of the inquiry, the ISC sought to investigate the killing of Khan as well as U.S.-led operations against British targets in Iraq and Syria. As the government refused to cooperate, it was agreed in an exchange of letters between th ISC and the PM that the Committee would limit the scope of its inquiry to the strike on Khan and avoid other incidents or larger themes. ${ }^{128}$

The Report revealed some uncertainties surrounding the government's decision-making process in the Khan operation. For example, it appeared that a mere "concern that, due to gaps in coverage, a plot might go undetected" might be taken by the government to satisfy the requirement that the individual in question posed an imminent threat to U.K. persons. In the end, the Committee concluded that it was unable to provide a normative assessment of this standard or the authorization process as a whole because it was denied access to Ministerial deliberations leading to the attack. ${ }^{129}$ Overall, the Executive's control of relevant information seemed to curtail the effectiveness of the investigation.

\section{The government's response to the inquiries}

The inquiries by the JCHR and ISC had sought to initiate a dialogue between Parliament and the government about the legal and policy foundations of the targeting policy. Yet the government's written response to the JCHR suggests that those hopes were largely in vain. ${ }^{130}$ To take one example, the Report's single most meaningful legal conclusion was that HRL-rather than IHLapplies to operations taking place outside armed conflict settings. ${ }^{131}$ The government, however, undermined the force of that conclusion by framing the question posed by the Committee on that is as a "hypothetical" question which does not require a "detailed and developed thinking." 132 In other parts, the government's response, although ambiguous, could reasonably be read to

127 ISC Report, supra note 18, at 1-3.

${ }^{128} I d$., at 3 .

${ }^{129} I d$., at $11,15,24$.

130 The Government's response is appended as Appendix 1 in JOINT COMM. ON HUMAN RTS., The GOVERnMENT'S POLICY ON THE USE OF DRONES FOR TARGETED KILLING: Government Response to the Committee’s Second Report of SESSION 2015-16.

${ }^{131}$ JCHR Drones Report, supra note 18, at 59-60.

132 The Government's response is appended as Appendix 1 in JOINT COMM. On HuMAN RTS., THE GOVERnMENT's POLICY ON THE USE OF DRONES FOR TARGETED KILLING: Government Response to the Committee's Second Report of Session 2015-16, 2016, HL 49, HC 747, (U.K.) (hereinafter, FCHR Fourth Rep. of Session 16-17). 
reject the JCHR views. It noted that "in relation to military operations, the law of war would be likely to be regarded as an important source in considering the applicable principles"-but said nothing about the applicability of the ECHR. ${ }^{133}$ It also did not provide clarifications regarding the meaning of "imminent threat" and the standards for supporting operations led by allies, and refused to reconsider its apparent position that decisions to use force are matters concerning which the courts have no jurisdiction. ${ }^{134}$

The government's reluctance to work with the committees on developing an agreed-upon regulatory regime is consistent with its underlying view that the resort to lethal force overseas, in its own words "is within the government's discretionary powers under the Royal Prerogative." 135 This position suggests that, despite the active engagement of the JCHR and the ISC with the government's targeting policy, neither committee nor Parliament as a whole has been able to hold the government accountable in regards to its targeting policy. In addition, given the lack of judicial tradition and thus precedents in dealing with military activity overseas, it seems unlikely the British courts will scrutinize the government's targeting policy. ${ }^{136}$

\section{Israel: judicial review}

The eclectic corpus of laws, judicial doctrines, and political conventions that forms Israel's foreign relations law has shifted - from a model of executive control during the 1950s and 1960s to what can be described as a unique model of judicial supremacy that peaked in the early 2000s. One of Israel's Supreme Court's most influential decisions in this area was The Public Committee Against Torture in Israel v. Government of Israel (2006), in which the Court handed down the first court opinion worldwide on the legality of targeted killings. ${ }^{137}$ This Section will focus on this decision and its aftermath. After a

${ }^{133} I d$., at 16. In Al-Saadoon the Court of Appeal lends some support to the government's position in holding that the use of lethal force alone does not amount to the level of control required to bring an individual under the state's jurisdiction as required to trigger the ECHR. The meaning of the decision for our context is that, contrary to the JCHR position, the use of force overseas does not, in and of itself, trigger the ECHR regime. See Al-Saadoon v. Secretary of State for Defence [2016] EWGA Giv. 811 [U.K.].

${ }_{134}$ JCHR Fourth Rep. of Session 16-17, supra note 132, at 15-18, 23.

135 JCHR Drones Report, supra note 18, at 73.

136 An indication for the reluctance of the judiciary to weigh in on the matter is the Court of Appeal's dismissal of a case challenging the legality of the U.K.'s practice to provide intelligence for U.S.-led targeting operations on Act of State grounds. Noor Khan v. The Secretary of State for the Foreign and Commonwealth Affairs EWCA Civ. 24. [2014] (U.K.)

137 HCJ 769/02 The Pub. Comm. Against Torture in Israel v. Gov't of Israel, 57(6) PD 285 [2006] (Isr.). 
brief introductory note on the Court's general approach to cases implicating national security and foreign affairs, it will show how judicial action has been able to constrain the government, clarify the law governing targeted killings, and help developing accountability mechanisms. It will then analyze the limitations of this model and its failure to make legal accountability sustainable due to the judiciary's structural limitations. As with the previous sections, a normative assessment will follow in Part III.

A recent illustration of the modern Israeli approach to foreign affairs is the Supreme Court decision in Tziam v. the Prime Minister. ${ }^{138}$ Tziam concerned the implementation of a Cabinet decision authorizing a series of measures intended to put pressure on Hamas, a Palestinian-Islamic organization that controls Gaza since 2007, to return the bodies of two Israeli soldiers and two Israeli civilians who crossed the border to the Gaza strip several years ago and have been held captive since that time. One of the measures taken was the denial to relatives of Hamas members medical treatment ordinarily made available by to Gazans by Israel on a humanitarian basis. Five critically ill women from Gaza, denied entry into Israel for life-saving medical treatments, petitioned the Court seeking an injunction ordering their admission to East Jerusalem where they were scheduled to receive treatment in a nongovernmental medical center.

A panel of three judges ruled in favor of the petitioners. The ruling did not turn on familiar issues in foreign relations law such as the justiciability of the government's authority over entry (which may be viewed as a basic act of sovereignty), the legal right of aliens abroad to seek entry into the country, or the proper degree of deference to the executive in foreign affairs matters. ${ }^{139}$ Instead, the Court scrutinized the criteria employed by the government and held that an applicant's family ties to members of Hamas is not a lawful criterion for the denial of "life-saving humanitarian medical treatment."140 The Court opined that even when the government acts within its authority to pursue the return of the Israeli soldiers and civilians by applying pressure to Hamas, a sweeping denial or medical treatment based solely on affiliation with Hamas is a form of collective punishment, is unreasonable, and is therefore ultra vires (i.e., exceeds legal authority). ${ }^{141}$ One of the judges on the panel also criticized the rationale underlying the policy, noting that it is

138 HCJ 5913/18 Tziam v. the Prime Minister (Aug. 26, 2018) (Isr.).

139 Cf. Trump v. Hawaii, 138 S. Ct. 2392 (2018) (upholding a presidential proclamation restricting entry to the U.S. by nationals from seven - predominantly Muslim countries.

140 Tziam, at para. 24 (Vogelman J.).

${ }^{141} I d$., at para. 25-29. 
questionable whether denying medical treatment as a means of leverage over Hamas was effective. ${ }^{142}$

The rise of judicial power over security and foreign affairs arose piecemeal in Israel, facilitated by many historical, political, and sociological factors. ${ }^{143}$ Two jurisprudential developments were especially significant. First, since the late 1970s, the Supreme Court has narrowed justiciability barriers in foreign affairs cases. ${ }^{144}$ The Court has adopted an increasingly restrictive view of the non-justiciability doctrines and rarely invoked them when human rights were limited by a government action that lacked clear legal authority. ${ }^{145}$ This view resulted in a stream of cases implicating security and foreign policy, many of them arising from the military's treatment of the Palestinian population in territories captured by Israel in the 1967 war. ${ }^{146}$ Second, under the intellectual leadership of Judge Aharon Barak, President of the Court between 1994-2006, the Court ushered in a new approach that may be characterized as 'foreign affairs legalism' - the idea that every exercise of power by the state in this domain is controlled by law and nearly always suitable for adjudication. ${ }^{147}$ One pillar of this approach is that, when the controlling legal standard is vague or unsettled, it is the role of the judge to articulate it, consistent with the fundamental (albeit, more abstract) principles of domestic and applicable international law.

In the early 2000s, at the height of a particularly violent episode in the IsraeliPalestinian conflict, Israel launched a massive military campaign to eradicate terrorist pockets within Palestinian communities. During that period, the

142 Id., at para 2 (Amit J.).

143 For a comprehensive analysis see generally Amichai COHEn \& StuART A. Cohen, ISRAEL'S NATIONAL SECURITY LAW: POLITICAL DYNAMICS AND HISTORICAL DEVELOPMENT 143-67 (2012).

144 See, e.g., HCJ 390/79, Dweikat v. Gov't of Israel, 34(1) PD 1, [1979] (Isr.); HCJ 102/82 Tzemel v. Minister of Defense, 37(3) PD, 365 [1983] (Isr.). See also Eli Nathan, The power of Supervision of the High Court of fustice over Military Government, in MILITARY GOVERNMENT IN THE TERRITORIES ADMINISTERED BY ISRAEL, 1967-1980: THE LEGAL AsPeCTs (Meir Shamgar, ed., 1982).

145 See, e.g., HCJ 910/86 Ressler v Minister of Defence 42(2) PD 441(1988) (Isr.). See also COHEN \& COHEN, supra note 143, at 135 (surveying landmark cases); ZE'EV SEGAL, Standing Before the Supreme Court SitTing as a High Court of Justice (2nd ed., 1993) (in Heb.).

146 This was enabled initially by the decision of Meir Shamgar, then the Military Advocate General (and later the President of the Court), to not contest the jurisdiction of the Court over claims brought by Palestinian residents of the occupied territories. See David Kretzmer, The law of belligerent occupation in the Supreme Court of Israel, 94 INT'L. REV. RED CROsS 207, 209 (2012).

147 For the theoretical underpinnings of this approach See Aharon Barak, Foreword: $A$ Judge on Judging: The Role of a Supreme Court in A Democracy, 116 HARV. L. REV. 16 (2002). 
Court handed down decisions on military detentions, ${ }^{148}$ coercive interrogation techniques of suspected terrorists, ${ }^{149}$ the security barrier, ${ }^{150}$ various military tactics, ${ }^{151}$ and ultimately, targeted killing. ${ }^{152}$

\section{The Targeted Killing Case}

As early as 2000, Israel has acknowledged an official state policy of targeted killing in the context of the prolonged Israeli-Palestinian conflict. ${ }^{153}$ In addition, Israel reportedly carries out unacknowledged targeted strikes in other countries. ${ }^{154}$ According to the overt Israeli practice, decisions to use force against high-profile targets require ministerial authorization and legal approval by the Attorney General. This is in addition to a system of operational legal advice under the authority of the Military Advocate General (MAG), which reviews each selected target prior to submitting it for civilian approval and also advises the military during the targeting process. ${ }^{155}$

In 2002, two human rights organizations petitioned the Supreme Court in its capacity as the High Court of Justice (HCJ) for an injunction to prohibit the government from engaging in targeted killings. The petition was not a

148 HCJ 3239/02 Mar'ab v. IDF Commander in the West Bank, (Nevo legal Database (by sub.), 02/05/2003) (Isr.).

149 HCJ 5100/94 Pub. Comm. against Torture in Isr. v. The State of Israel, 53(4) PD 817, 845 [1999] (Isr.). (Isr.).

${ }^{150}$ HCJ 2056/04 Beit Sourik Village Council v. Gov't of Israel, 58(5) PD 817 [2004]

${ }_{151}$ HCJ 3451/02 Almandi v. The Minister of Defense, 56(3) PD 30 [2002] (Isr.) (military siege on a civilian compound); HCJ 3799/02 Adalah v. GOC Central Command, IDF, 60(3) PD, 67 [2005] (Isr.) (military practice known as "early warning procedure" whereby the military is aided by local Palestinian residents in detention operations).

152 For comprehensive analyses of the HCJ jurisprudence in cases relating to violence that erupted during the Second Intifada (2000-06) see Guy Davidov \& Amnon Reichman, Prolonged Armed Conflict and Diminished Deference to the Military: Lessons from Israel, 35 L. \& Soc. INQ. 919 (2010); Aharon Barak, International Humanitarian Law and the Israeli Supreme Court, 47 IsR. L. REV. 181 (2014); DAVID Scharia, Judicial REview OF NATIONAL SECURITY (2015).

${ }^{153}$ From its very first days in 1948, Israel - through its intelligence agencies - engaged covertly in targeted assassinations of individuals who were believed to pose a threat to national security (and, rightfully or not, to its very survival). See generally RONEN BERGMAN, Rise AND Kill First: The SeGret History OF IsRaEL's TARgeted Assassinations (2018). In 2001, Israel first made its targeted killing policy of alleged terrorists public, reporting the killing of Hussein Abayat, a senior leader of the Palestinian armed group 'Fatah Tanzim.' See Blum \& Hyman, supra note 14, at 4.

154 See e.g., Diaa Hadid \& Anne Barnard, Commander of Hezbollah Freed by Israel Is Killed in Syria, N.Y. Times (Dec. 20, 2015)

https://www.nytimes.com/2015/12/21/world/middleeast/samir-kuntar-hezbollahsyria-israel.html.

${ }^{155}$ Id. See also, Michael N. Schmitt \& John Merriam, The Tyranny of Context: Israeli Targeting Practices in Legal Perspective, 37 U. PA. J. INT'L L. 53, 70-87 (2015). 
response to one concrete strike; rather, it requested that the court abrogate the policy on the grounds that under either paradigm (armed conflict or law enforcement), the premeditated and intentional killing of alleged terroristswho, the petitioners argued, are 'civilians' under international law - is unlawful. ${ }^{156}$ The government denied the Court's jurisdiction and alternatively argued that its policy complied with IHL, which it viewed as the applicable law. ${ }^{157}$ The government's legal justification rested on the view of terrorists as unlawful combatants who may be targeted at all times during armed conflict. ${ }^{158}$

The judgment did not adopt either position. Instead, the Court articulated a legal standard for when such use of lethal force is permitted, provided guiding principles for its implementation, and placed procedural guarantees that must be met before and after every operation. The Court premised its analysis on the existence of an international armed conflict between Israel and Palestinian armed groups. ${ }^{159}$ Accordingly, the legal standard rested on the IHL rule on civilians taking direct part in hostilities (DPH), rejecting the government's view of terrorists as (unlawful) combatants. The Court, nonetheless, adopted a broad reading of the DPH rule that allowed the government to maintain the culpability of members of armed groups not only during but also between acts of direct participation in hostilities. ${ }^{160}$ It supplemented this standard with a least-harmful-means test (i.e., that the use of force is prohibited when capture is feasible) and additional procedural requirements for pre-strike enhanced legal vetting and post-hoc independent investigation. ${ }^{161}$ Notably, these limiting principles were not required by IHL but rested on general principles of Israeli administrative law.

\section{Judicial oversight and continuity}

This wholesale regulation of counterterrorism targeting in a single judicial opinion was a dramatic development but placed a significant burden on the judiciary: in a sense, the Court legitimized the use of targeted killing, and felt compelled to guarantee that actual practice did not fall short of what the opinion required. For this purpose, the opinion ordered the establishment of an executive post-hoc investigation mechanism and provided that this

156 The Targeted Killing case, supra note 137, at $9 \uparrow$ 3-8.

${ }^{157} \mathrm{Id}$., at 9 9-13. At the time, the government's justiciability claim was grounded in HCJ case law. See HCJ 5872/01 Barakeh v. The Prime Minister 65(3) PD 1, 1 [2002] (Isr.) ("the choice of means of war employed by respondents to prevent murderous terrorist attacks before they happen, is not among the subjects in which this Court will see fit to intervene").

158 Brief for Respondents (Feb. 2, 2003), HCJ 769/02 The Pub. Comm. Against Torture in Israel v. Gov't of Israel, 57(6) PD 285 [2006] (Isr.).

159 The Targeted Killing case, supra note 137, at 9 16-23.

$160 \mathrm{Id}$., at 939.

161 Id., at $₫ 40$. 
mechanism will be accountable to judicial supervision. ${ }^{162}$ However, it must be noted that this mechanism was not formed until 2014 and its procedures are classified. To date, only one investigation is known to have been completed. ${ }^{163}$ In light of a decrease in targeted killings in recent years and the dysfunctionality of the investigation mechanism, the HCJ has revisited the issue sporadically and only indirectly. ${ }^{164}$

Formally, the Targeted Killing case still controls the conduct of operations of the Israeli Defense Forces (IDF). But at least since 2014, the Military Advocate General International Law Department (ILD), which is charged with providing operational legal advice to all branches of the IDF, has adopted a restrictive view of its scope and adopted a more permissive approach to targeting in certain situations. ${ }^{165}$ It should be remembered that the HCJ reasoned that alleged terrorists are 'civilians' and thus may be targeted only when they take direct part in hostilities: killing them based solely on their status as members of terrorist groups was deemed illegal. ${ }^{166}$ In contrast, the ILD has limited the applicability of Court's reasoning to lone-wolf terrorists and adopted a status-based approach to members of organized armed groups, arguing that such members "may be attacked at any time by the sole virtue of their membership."167

To be sure, there may be legitimate reasons to deviate from some of the conclusions of the Targeted Killing opinion: the factual circumstances in the

162 Id., at 159.

163 See Amir Oren, the Targeted Killings Committee that the IDF established but kept secret, HA'ARETZ (May 31, 2014) (Heb). Prior to the establishment of a permanent committee the government formed an ad-hoc body to investigate the killing of Salah Shehadeh, a senior figure of Hamas military wing in Gaza, who was killed in 2002 alongside 14 civilians. That committee was formed in response to a petition submitted to the HCJ by several human rights organizations challenging the MAG's decision not to order criminal investigation of the attack. Its report was published in 2011. See Special Investigatory Commission Report: Salah Shehadeh (Feb. 11, 2011) (Isr.).

http://www.pmo.gov.il/SiteCollectionDocuments/PMO/32communication/spokemes/re portshchade.pdf

164 In a number of cases the HCJ considered allegations concerning military noncompliance with the Targeted Killings case. See e.g., HCJ 8794/03 Hes v. the Chief Military Advocate General [Dec. 3, 2008] (Isr.) (rejecting a petition challenging the decision not to hold criminal investigation of the targeted killing of Hamas senior Salah Shehade which also caused 14 civilian deaths).

165 See State of IsRael, the 2014 Gaza Conflict: Factual and Legal Aspects, at 264 (2015) (laying out the Israeli legal position on the rules governing targeting operations) (hereinafter, the 2014 Gaza Conflict Report) .

166 The opinion nonetheless acknowledged that "a civilian who has joined a terrorist organization which has become his 'home', and in the framework of his role in that organization he commits a chain of hostilities" loses his civilian immunity for as long as he maintains his active role in the hostilities. The Targeted Killing case, supra note 137, at 39.

167 The 2014 Gaza Conflict Report, supra note 166, at 9264. 
Gaza strip have indeed changed dramatically; new customary international law may have been formed. ${ }^{168}$ Yet any adoption of a new standard must be consistent with the Court's opinion, which is higher law in Israel than customary international law. It is unclear whether the ILD's unilateral decision to adopt a different legal regime satisfies this requirement, yet the fact that resolving this issue requires a petitioner who will bring the question in case before the court-something that, thus far, did not happen-raises questions about the long-term efficacy of the Israeli model.

\section{NORMATIVE ASSESSMENT}

This Part discusses the normative insights obtained from the foregoing comparative analysis and then consider how those insights may be combined into concrete recommendations.

\section{A. Key insights}

\section{The structural deficiency of the legislative process}

A common feature of the U.S., U.K, and Israeli models is the legislative institutions' lack of influence on the behavior of the executive. In each instance, legislative oversight proved powerless to cause the government rethink policy, alter legal positions, or modify decision-making processes. It follows that regulatory models that will rely on the legislative process to police executive action in this area will in effect be equivalent to models that trust the executive to police itself. Arguably, they might even be worse because they create an appearance of political accountability.

The complete failure of the political process is especially remarkable in the case of the U.K., where the constitutional framework is founded on political accountability and where institutions within Parliament have effective tools to scrutinize government conduct. To be sure, the system did not break down entirely: the ISC and, especially, the JCHR, have performed rather well within the scope of their respective authority and given the resources available

168 In the wake of the 2014 Gaza Conflict, Professors Michael Schmitt and John Merriam conducted extensive field research in which they visited the Israeli operations center and interviewed key IDF legal advisers. In a law review article summarizing the study, they offered two grounds for distinguishing the targeted killings case from current Israeli practice: (1) that the groups Israel faces have become more "organized and combat effective" than they were in 2006; (2) that "the notion of 'organized armed groups' as armed forces for targeting purposes" emerged in 2009 and is now generally accepted as customary international law. See Schmitt \& Merriam supra note 155, at 111. For a critical analysis of these explanations see Yahli Shereshevsky, Targeting the Targeted Killings Case - International Lawmaking in Domestic Contexts, 39 MiCH.J. INT'L L. 241, 250-53 (2018). 
to them. The problem has been more one of institutional design. In the case of the ISC, the critical issue was the government's control of information, which limited both the scope of the ISC's investigation and the evidence on the basis of which it evaluated the merits of the case. ${ }^{169}$ As for the JCHR, the Achille's heel of the entire exercise was the Committee's incapacity to issue a binding opinion. A basic premise of the British model of rights protection is the "soft power" approach - the idea that although JCHR reports are legally oriented, they are not legally binding. ${ }^{170}$ The primary function of legislative human rights scrutiny is to help embed the importance of those rights in the work of Parliament and the government, as well as to raise the political costs of disregarding human rights concerns. ${ }^{171}$ The problem is that when this model is invoked in the national security context - especially when the issue involves the rights of foreigners - those costs are relatively low and the government is unlikely to cede powers it deems necessary to counter a threat.

In addition to the drone inquiry, this is the lesson of other JCHR inquiries during national security crises. For example, shortly after the 9/11 attacks, the government laid before Parliament the Anti-Terrorism, Crime, and Security Bill, a comprehensive counterterrorism scheme that gave law enforcement authorities far-reaching powers, including indefinite detention of foreigners where deportation was legally or practically preempted. ${ }^{172}$ In a series of reports, the Committee took a critical view of those powers and the emergency regime that enabled them. ${ }^{173}$ It asked Parliament to reassess the necessity of the derogation order (in which the government de-facto declares a state of emergency) and, after the bill was passed despite its views, pressed the government to replace the detention scheme "as a matter of urgency." 174

\footnotetext{
169 See supra text accompanying notes 127-29.

170 See supra note 110-26.

${ }^{171}$ Michael C. Tolley, Parliamentary Scrutiny of Rights in the United Kingdom: Assessing the Work of the foint Committee on Human Rights, 44 Australian J. Poly. SaI. 41, 47 (2009).

172 The Anti-terrorism, Crime and Security Act 2001, c. 24 (U.K.) (amended, current version at https://www.legislation.gov.uk/ukpga/2001/24/contents). Before the introduction of the Bill in Parliament, the Home Secretary notified the Secretary General of the Council of Europe of the Government's intention to take measures derogating from the Convention. See the Human Rights Act 1998 (Designated Derogation) Order 2001, No. 3644 (U.K.).

173 See Joint Comm. on Human Rts., Second Report: Anti-Terrorism, Grime And Security Bill, 2001, HL 37, HC 372, (U.K.); Joint Comm. On Human Rts., Fifth RePOrt: ANTI-TERrorism, Grime AND SEGURITy BILL-FUrTHER REPORT, 2001, HL 51, HC 420, (U.K.); JoInt COMm. On Human RTS., Fifth RePORT: CONTINUANCE In ForCE of Sections 21 to 23 of the Anti-Terrorism, Grime and SEGurity AGt of 2001, 2003, HL 59, HC 462, (U.K.); Joint Comm. on Human Rts., Eighteenth Report: Review OF COUNTER-Terrorism POWERs, 2004, HL 158, HC 713, (U.K.) (hereinafter, JCHR Eighteenth Rep. of Session 03-04).

${ }^{174}$ JCHR Eighteenth Rep. of Session 03-04, supra note 174, \} 3 2 .
} 
But neither the government nor Parliament heeded the JCHR's concerns. The political process failed to achieve anything other than some modest amendments. Rather, it was a judicial ruling that ultimately led to the revocation of the detention scheme. In $A$. $v$. Secretary of State, the House of Lords found the detention provisions "draconian" and incompatible with the ECHR. ${ }^{175}$ Following the declaration of incompatibility, the detention authority was repealed and replaced by the Prevention of Terrorism Act 2005, which put in place a new regime of control orders. ${ }^{176}$

The failure of the political process to check executive national security powers is by no means unique to the Westminster system. During the 17-year war on terror, the U.S. Congress has proven itself unable to effectively regulate the President's claimed authority to employ targeted killing. Over a decade, and across four administrations, counterterrorism targeting was expanded to include new territories, new armed groups, and new methods (e.g., signature strikes). At that time, Congress failed in its attempts to repeal or replace the 2001 AUMF. ${ }^{177}$ Further attempts to increase routine monitoring by Congressional committees were also ineffective, much like in the British example, owing to executive control of classified information. ${ }^{178}$

Both the British and American examples of the (sometimes self-inflicted) marginalization of the legislature find support in political science literature. Scholars have portrayed the British legislature as an 'arena legislature,' a forum in which public debate takes place but policy is rarely shaped. ${ }^{179}$ And indeed, historically, when national security has been at stake, Parliament delegated extraordinary powers to the government to deal with the threat, including powers which in retrospect were understood to deviate from the

175 A. v. Secretary of State for the Home Dep’t. [2004] UKHL 56, ๆ 43 (U.K.).

176 Prevention of Terrorism Act 2005, c.2 (U.K.) (repealed by Terrorism Prevention and Investigation Measures Act 2011, c. 23 (U.K.).

177 See supra note 81.

178 For example, in 2014 the Senate Armed Services Committee sought to convene a joint classified hearing with the Senate IC to assess operations involving both CIA and the Joint Special Operations Command (JSOC). Again, the White House barred effective review by refusing to grant security clearances to members of the Armed Services Committee necessary for briefings on covert CIA operations. See The Stimson Genter, RECOMMENDATIONS AND Report THE TASK ForGE ON US DRONE POLICY, 38-39 (2014)

179 See Nelson W. Polsby, Legislatures, 277-92 in Handbook of Political Saience (Fred I. Greenstein \& Nelson W. Polsby eds., 1975); Meg Russell \& Daniel Gover, LEGISLATION AT WESTMINSTER: PARLIAMENTARY ACTORS AND INFLUENCE IN THE MAKING OF BRITISH LAW 4 (2017). The literature further notes the limited impact of Parliament's Foreign Affairs Committee on policymaking. See MCLACHLAN, supra note 98, at 183-84. This lends further support to the conclusion that the effort to check the government's conduct of foreign affairs through the political process is futile. 
British constitution. ${ }^{180}$ Similarly, scholars of the American presidency have found that the unitary nature of the institution, the fact that "virtually all authoritative governmental decisions are made within the executive," and the expertise and resources available to presidents put them in a position "to shift the status quo by taking unilateral action on their own authority, whether or not that authority is clearly established in law." 181 Specifically, because the subject matter is not politically rewarding, foreign policy issues tend to encourage legislative inaction or broad delegations of authority to the President. ${ }^{182}$ While there are notable exceptions, they are rare and, for the most part, represent a concrete response to a public scandal (such as Abu Ghraib $^{183}$ ) or unpopular wars. ${ }^{184}$ In general practice, legislators rarely challenge the government in the areas of national security and foreign affairs.

Overall, the literature and historical examples suggest that the ineffectiveness of legislatures in this domain reflects structural and enduring problems. As a result, models that trust the political process to regulate the power to use force in counterterrorism operations are practically equivalent to models that trust the executive to police itself.

\section{The inadequacy of self-regulatory regimes}

A useful way to begin assessing a regulatory regime designed and enforced exclusively within the executive is to consider the changes made by President Trump to President Obama's targeting policy. The Obama administration developed what I earlier described as a two-tiered framework of broad

180 A good example is the Defence of the Realm Act 1914, which was enacted at the outset of World War I. As described by Clinton Rossiter: "the Cabinet went into Commons and demanded the immediate passage of a remarkable aggregation of emergency laws, and these laws, prepared in advance by the pertinent ministers or by the Committee of Imperial Defence, were suddenly spewed forth without debate, without alteration, and without protest." Clinton Rossiter, CONSTItUtional DiGtatorship: CRisis Government in The Modern Democracies 153 (2002 ed.). Other notable examples are the Civil Authorities (Special Powers) Act, 1922 and the Anti-Terrorism, Crime, and Security Act 2001.

181 See Moe \& Howell, supra note 60, at 142. For particular illustrations, see, e.g., JOHN H. Ely, War AND Responsibility ix, 47-52 (1993) (Congress' involvement in the Vietnam War); Aziz Z. Huq, Structural Constitutionalism as Counterterrorism, 100 CALIF. L. REV. 887, 91843 (2012) (Congress' involvement in post-9/11 counterterrorism oversight); AMY ZEGART, Eyes ON SPIES: CONGRESS AND THE United StATES INTELLIGENCE COMMUNiTy (2011) (Congressional intelligence oversight).

182 Id., at 141. See also Zegart, supra note 182, at 64-85 (noting that American voters typically do not rank foreign policy high on their list of issues; explaining that by virtue of a lack of direct and noticeable impact on constituents, as well as its secret nature, intelligence oversight appeals to a few, weak interest groups).

183 See the Detainee Treatment Act of 2005, Pub. L. No. 109-148, 119 Stat. 2739.

184 See e.g., The War Powers Resolution 50 U.S.C. $\$ \S 1541-1548$ (2012) (the law was enacted over President Nixon's veto on the heels of the unsuccessful Vietnam War). 
assertion of legal authority coupled with restricting policy rules and procedures. The PPG came in response to growing criticism over the extensive use of drones for targeted killings in multiple arenas, ${ }^{185}$ and soon became the hallmark of Obama's counterterrorism strategy, a model of presidential 'selfchecking'. ${ }^{186}$ President Obama and his legal team were proud of the fact that the PPG was more restrictive than what the law required, ${ }^{187}$ but that fact obscured the controversial legal positions underlying the policy at the levels of both domestic and international law. ${ }^{188}$ When President Trump took office and, without reporting to the public, replaced the PPG with the more permissive PSP, the controversial legal claims remained - but most of the limiting principles ceased to exist. 189

This example illustrates a deeper problem with self-regulatory regimes. Regardless of their ideological convictions or policy preferences, presidents seek power; in order to accomplish their goals and satisfy their ambitions in the limited time they have, they strive for control and flexibility. ${ }^{190}$ Imposing limitations on the scope of presidential power goes against their nature. This helps explain the pattern of expanding unilateral power to use targeted killing and, more broadly, the growth of presidential control over foreign affairs. Every president has built on the foundation established by his predecessors and refused to cede powers which they have already invoked. Sometimes presidents may have a political interest in obscuring their desire to retain powers claimed by another president they want to distinguish themselves from (Barack Obama and George W. Bush immediately come to mind) and, therefore, will use various signals as a means of showcasing self-restraint. But this is not sufficient to create accountability. One way to understand the PPG is as a signal to elites, liberal constituents and foreign allies that the infamous 'war on terror' was transformed under the leadership of President Obama

185 See SAVAGE, supra note 89 at 239-44, 282-90 (2015), (reporting the circumstances leading to the formulation of the restrictive policy rules governing targeted killing).

186 To recall, the PPG limited the use of force when civilian casualties were foreseeable, placed a least-harmful-means requirement, and required an elaborate, high-level vetting process - some operations required no less than presidential approval. PPG, supra note 55, at $1-3$.

187 See, e.g., Obama May 2013 speech, supra note 7 ("[t] s say a military tactic is legal, or even effective, is not to say it is wise or moral in every instance. [...] And that's why, over the last four years, my administration has worked vigorously to establish a framework that governs our use of force against terrorists -- insisting upon clear guidelines, oversight and accountability that is now codified in Presidential Policy Guidance that I signed yesterday").

188 See supra notes 86-90 and accompanying text.

189 See supra note 94-96 and accompanying text.

190 See generally Moe \& Howell, supra note 60; Stephen Skowronek, The Politias Presidents MAKE: LeAdership From JOHn AdAMS TO GEORGE Bush (1993); RiCHARD E. Neustadt, Presidential Power and the Modern Presidents (1990); Theodore Lowi, The Personal Presidency (1985). 
into a human rights-respecting counter-insurgency campaign. ${ }^{191}$ Note, however, that the adoption of the PPG did not entail any constraints on presidential discretion, just as the shift to Trump's PSP did not entail a claim of new powers. Policy frameworks such as the PPG and PSP are subject to the ultimate authority of the President and, by delegation, of his staff. Scholars have shown that officials have loosely interpreted the rules set by those frameworks; ${ }^{192}$ suspended and re-imposed them in certain arenas to serve immediate needs; ${ }^{193}$ and each administration has treated its policy framework differently in terms of transparency. ${ }^{194}$

None of this is illegitimate. But insofar as rules and procedures are meant to regulate behavior and constrain the discretion of policymakers - including the Chief Executive, those instruments clearly fall short.

It may be suggested that even if policy instruments such as the PPG do not constrain the Executive, the law does. ${ }^{195}$ While this may be true in theory, in practice presidents have direct and indirect ways to exercise control over how the law is interpreted and implemented within the executive branch. ${ }^{196}$ The 'executive-friendly' meaning given to the legal frameworks governing the use of force in counter-terrorism operations by all recent administrations (as well as by the UK and Israeli governments) serves as a reminder that striving for

191 For instance, in at least one known case the U.S. permissive approach to targeting seemed to undermine intelligence sharing by European states. See Anthony Dworkin, Drones and Targeted Killing: Defining a European Position, Eur. Council on For. Rel., at 3. (2013).

192 See Shirin Sinnar, Rule of law Tropes in National Security, 129 HARV. L. REV. 1566, 1570, 1600-04 (2016) (arguing that policy rules often include legal terms of art, but allow meanings that "deviate, at least partly in secret, from prevalent understandings of those terms").

193 President Obama temporarily designated Libya an area of active hostilities when U.S. forces aided the fighting against ISIL. Charlie Savage, U.S. Removes Libya From List of Zones with Looser Rules for Drone Strikes, N.Y. Times (Jan. 20, 2017), https://www.nytimes.com/2017/01/20/us/politics/libya-drone-airstrikes-rules-civiliancasualties.html. President Trump recently designated Yemen an area of active hostilities. Charlie Savage \& Eric Schmitt, Trump Eases Combat Rules in Somalia Intended to Protect Civilians, N.Y. Times (Mar. 30, 2017),

https://www.nytimes.com/2017/03/30/world/africa/trump-is-said-to-ease-combatrules-in-somalia-designed-to-protect-civilians.html.

194 See supra note

195 The question whether law constrains presidents has provoked sharp debates in legal scholarship. See, e.g., Posner \& Vermeule, supra note 16, at 113-53; Curtis A. Bradley \& Trevor W. Morrison, Presidential Power, Historical Practice, and Legal Constraint, 113 CoLuM. L. REv. 1097, 1132-45 (2013); Aziz z. Huq, Binding the Executive (by Law or by Politics) (Book Review), 79 U. ChI. L. Rev. 777 (2012); Richard H. Pildes, Law and the President (Book Review), 125 Harv. L. Rev. 1, 42 (2012); BruGe AGKerman, The DeGline and Fall of THE AMERICAN REPUBLIC (2010).

196 See Elad D. Gil, Totemic Functionalism in Foreign Affairs Law, 10 HARV. NAT’L. SEG. J. 316, 336-39 (2019) (analyzing how the institutional structures of legal advice mechanisms within the executive branch enable presidential influence on legal decision-making). 
flexibility and control also informs legal interpretation inside the executive branch. As long as other political actors do not become involved in defining clear limits to what qualifies as reasonable interpretation, executives will keep pushing the envelope. As the British example suggests, this conclusion is equally true in legal systems in which the executive is formally accountable to the legislature: viewed from this perspective, it seems plausible that the reluctance of the U.K. government to provide clear answers to the questions presented by the JCHR regarding applicable law and the decision-making process were driven by its desire to retain flexibility and independent discretion over the targeting policy. As such, its response seems as an illustration of the agency costs problem of representative democracies and is likely to repeat itself in the future.

\section{The virtues and vices of judicial review}

Can the courts do better than the other institutions? The short answer is a qualified yes. Evidently, only the Israeli model has produced a binding, comprehensive, and sufficiently transparent legal scheme for regulating the use of force for counterterrorism, which it made available for the public eye. ${ }^{197}$ The Targeted Killings case clarified the conditions set by the IHL norm governing targeted killing of suspected terrorists. The Court then wisely identified that international law on the topic was amorphous and underdeveloped - simply declaring what IHL required would have provided very little guidance in the context of targeting terrorists. Accordingly, the judgment laid out additional requirements, both substantive (a least-harmfulmeans requirement) and procedural (enhanced pre-strike legal vetting, independent post-hoc investigation), which the Court rested on domestic administrative law doctrines. ${ }^{198}$ The announcement of the judgment, which, as noted, rejected some of the key legal positions of the government's policy, had an immediate effect on the conduct of IDF operations. ${ }^{199}$ The Court promulgated new law that required all branches of the military to modify orders and implement a structured form of decision-making.

In terms of accountability and consistency with the rule of law, the Targeted Killings case was rightly celebrated as a significant accomplishment by commentators. ${ }^{200}$ It provided clarity and normative stability - no executive

197 See supra Sec. II.C.1.

198 That analytic move relied on earlier precedents in which the Supreme Court held that military activities are governed by administrative law principles. In this context, Israeli law may be distinguishable from the U.S. Administrative Procedures Act model of judicial review that excludes "military authority exercised in the field in time of war or in occupied territory." 5 U.S.C. $§ 551(1)$.

199 Interview with IDF MAG officer R (on file with author).

200 See, e.g., Roy S. Schondorf, The Targeted Killings Judgment: a Preliminary Assessment, 5 J. Int'l Crim. Justice 301, 301 (2007); MeLZER, supra note 3, at 32-36; OWEN FISS, A WAR LIKE 
official, including the Prime Minister, was authorized to disregard the legal standard announced by the Court. Moreover, the decision mandated a structured decision-making process that seems especially suitable to the nearadjudicative process though which people are nominated for lethal targeting. It is likely that procedural guarantees that traditional war targeting does not legally require but the Court found vitally important in this context have mitigated the risks of error of judgment or abuse of discretion. (Note that following the decision, the pace of strikes and accompanying civilian death tolls declined dramatically. However, given that by the time the Court delivered the judgment the violence that erupted in 2000 had waned, one cannot point to a clear correlation between the opinion and the decline in number of strikes and total casualties.)

Finally, along with other landmark cases relating to military activities against terrorist organizations, the Targeted Killing case has helped elevate the role of bureaucratic experts, specifically lawyers, in the decision-making process. In the last two decades, the IDF operational legal advice mechanism has grown substantially in size and influence. ${ }^{201}$ One reason for this trend has been the activist posture of the Court during the escalation of the Israeli-Palestinian conflict. ${ }^{202}$ As perhaps the "only judicial body in the entire world which has demonstrated its willingness to enforce IHL on the army ex ante, that is, before an action is taken, or even whilst a military operation is in progress," the Court has indirectly reinforced the functional role of legal advice in the military and other national security agencies. When executive action must pass judicial muster, the "clients"- that is, government and military officials - are more likely to seek competent legal advice, which accurately predicts what actions would survive judicial scrutiny, even if that advice limits their discretion. This dynamic enhances the lawyers' functional independence and mitigates pressure by policymakers for overlyaccomodating legal opinions. As confirmed by one MAG officer in an interview, lawyers often use the prospect of judicial review to urge acceptance of their legal position. ${ }^{203}$ At the same time, the anticipation that their advice

NO OTHER 262-85 (2015); Tamar Meshel, A Decade Later and Still on Target: Revisiting the 2006 Israeli Targeted Killing Decision, 7 J. InT'L Human. Legal Stud. 88 (2016).

201 See Schmitt \& Merriam supra note 155, at 85-93; Amichai Cohen, Legal Operational Advice in the Israeli Defense Forces: The International Law Department and the Changing Nature of International Humanitarian Law, 26 CONN. J. INT'L. L. 367 (2011).

202 The indirect influence of judicial action has been termed in the literature as the "observer effect." See Ashley S. Deeks, The Observer Effect: National Security Litigation, Executive Policy Changes, and Fudicial Deference, 82 Fordham L. Rev. 827 (2013) (noting that, "at least when the executive reasonably can foresee that a court may step in to review particular security policies," its policies tend to draw the lines "closer to where courts likely would uphold them").

${ }^{203}$ Interview with IDF MAG officer R (on file with author). 
may be tested in court restrains the lawyers and assures that their advice will be cautious, well reasoned, and insulated from policy preferences and shortterm operational needs.

Notwithstanding these important benefits, there are at least two reasons for concern. For one, the developments in Israel since 2014 point to a critical deficiency of the judicial model. The only mechanism through which judgemade legal standards can be amended to meet changing factual/legal circumstances is by subsequent cases brought before the court. This is a slow process that occurs sporadically, and might put decision-makers in a situation when they must decide whether to distinguish the controlling case-law and deviate from the governing standard or to follow the case-law even when the circumstances in which it was decided have changed dramatically.

Second, and more profoundly, insofar as the law is genuinely ambiguous with respect to counterterrorism targeting, it is not clear why the court is the proper political actor to clarify its meaning and set additional limits on government action. Since most, if not all international law in this context is customary in nature, the state's position vis-à-vis the emerging customary norm is not purely a legal question but also one of foreign policy. It may be prudent for judges, who lack authority (and expertise) in foreign policy, to be cautious before they hamstring government in its efforts to influence the trajectory of emerging international law. As one scholar put it, maybe "ambiguity in legal sources should rebound discretion to [the policymakers], not the lawyers." 204 It then might be better, runs the argument, that judges would defer to the Executive when cases implicate such foreign policy concerns, particularly when they (de-facto) involve international lawmaking.

This view seems attractive at first glance, but it is premised on a false either/or dichotomy: we can either have executives sufficiently empowered to successfully pursue foreign policy objectives, or we can have executive accountability through the court system. But these are not two mutually exclusive alternatives. It is "essential that there be definite limits to the government's discretion," and, as we have seen, when the Executive is left to police itself it has no incentive to state where those limits are. ${ }^{205}$ Courts can be valuable in policing executive conduct while recognizing a considerable space for the Executive to shape its foreign policymaking within the confines of the law. In the targeting context, the judicial role is to ensure that policy preferences do not exceed legal boundaries or rely on indefensible interpretations of the governing law, and that the procedures practiced by the government meet a minimal threshold of procedural due process.

204 Renan, supra note _, at 885.

205 Trump v. Hawaii, 138 S. Ct. 2392, 2448 (2018) (Sotomayor J., dissenting). 


\section{B. Parameters for possible institutional reforms}

In light of the foregoing, it is clear that no one model has the 'perfect' formula that reconciles all of the competing social interests involved. I do not contend that there is a one-size-fits-all model to deal with the complexities of regulating the use of targeted killings. But the different structures through which the United States, Britain, and Israel - the three leading forces in the West dealing with extraterritorial ideological political violence -allocate decision-making authority over the use of lethal force are illuminating for policymakers contemplating this tactic. Based on their experiences, I conclude by proposing parameters for possible institutional reforms.

- Policymakers should be mindful that counterterrorism targeting is fundamentally different from traditional military targeting. In many ways, the collection and assessment of evidence and the intellectual exercise of deeming an individual targetable have more in common with criminal proceedings than with a field officer ordering his sergeant to shoot the enemy. The processes through which people are nominated for targeting must involve procedural safeguards which are, to some degree and subject to secrecy limitations, akin to those applicable in the criminal context.

- A government committed to the rule of law must anchor its targeting policy in a clearly spelled out legal standard. Such standard is ought to clarify the conditions for lethal targeting and define minimal procedural guarantees to ensure efficient decision-making and fairness. If made public (and it should), such standard may also help hold government officials accountable, and give reasonable notice to potential targets of the type of behavior that renders them targetable.

- Given the ambigous state of international law in this area and the novel challenges presented by global terrorism, the project of creating and enforcing the legal standard is too complexed and important to leave exclusively in the hands of those whose behavior is regulated by it. Executives are more informed and better equipped with relevant knowledge and expertise than other actors to ensure optimal trade-offs between the different interests involved. Yet their incentive structure is built to maximize power rather than imposing limitations. Experience shows that only where courts were involved in overseeing targeted killing, such legal standard emerged. Moreover, where the potential of judicial action is more likely, intra-executive review mechanisms are more powerful in urging caution on policymakers. The precise function courts should perform in this process depends on many constitutional, procedural, and other factors which are country-specific, and thus cannot 
be articulated on an abstract level. Nonetheless, given the limitations of the political process and internal review mechanisms, some judicial involvement is crucial.

- An important lesson from the challenges presented by the Israeli model is that there must be procedural outlets for plaintiffs to bring legal challenges to alleged deviations from the standard set by existing law or initial court decision. As noted, the Israeli model failed to provide such an outlet, and the constraining effect of the decision has waned until the judgment was formally distinguished by the ILD in cases involving members of organized armed groups. ${ }^{206}$ One such outlet might be tort litigation, which has some important advantages. Using monetary compensation can both deter unlawful behavior and provide redress for victims. ${ }^{207}$ Moreover, by its nature, tort litigation is pursued ex-post, and is thus less likely to interfere with the executive's national security decision-making. But in light of procedural and evidentiary hurdles, as well as the concern that litigation would compromise national security interests, most legal systems bar damages suits arising from military activities overseas. ${ }^{208}$ Another possible outlet is administrative litigation, which is practiced in Israel and was recently unsuccessfully attempted in the U.S. ${ }^{209}$ Indeed, the administrative track was only partly successful in Israel: on the one hand, the Targeted Killing case was an administrative case, and most of the procedural and substantive tests ordered by the opinion were derived from administrative law doctrines. On the other hand, Judge Barak's opinion anticipated that the Court will continue to oversee targeting decisions by reviewing the work of an executive branch investigation mechanism that, according to the opinion, was intended to probe into every targeted strike post-factum. ${ }^{210}$ The problem, of which Judge Barak was not mindful, was that setting up the mechanism and creating appropriate procedures that attract victims and third parties to provide relevant information was not a high-priority for the government. From its inception, government control of the mechanism rendered it toothless as a subject for administrative litigation.

206 See supra Section II.C.2.

207 For the potential benefits of tort litigation in the context of counter-terrorism see generally Gilat J. Bachar, Collateral Damages: Monetary Compensation for Civilians in Asymmetric Conflict, 19 CHI.J. INT'L. L. 375 (2019).

208 Id., at 397-408.

209 See Zaidan v. Trump, 317 F. Supp. 3d 8 (D.D.C. 2018). In that case, Ahmed Zaidan and Bilal Kareem, two journalists who regularly report from conflict zones in the Middle East, challenged the alleged decision to include them on a government "kill list" under, among other grounds, the Administrative Procedure Act (APA).

210 The Targeted Killing case, supra note 137, at 959. 
Overall, the Israeli experience emphasizes the importance of ensuring a procedural outlet to fully realizing the potential of the judicial review model.

- The legislative process faces many structural obstacles which render it unsuitable to micromanage the law and policy of targeted killings. The legislative process should focus on promoting transparency - for example, by imposing reporting duties on the executive, and creating avenues for judicial review. This may be done either by creating a direct cause of action for victims of unlawful strikes, ${ }^{211}$ or by setting up administrative bodies to investigate strikes after the fact. These bodies should have the power to summon witnesses and to consider evidence submitted by both government and non-government sources; their work should be subject to judicial review.

\section{CONCLUSiON}

Nations, even those that share common values and a legal tradition, differ in how they organize authority relating to foreign affairs and national security. Their differences reflect historical experience, legal and political culture, military and economic power, and the complexity of contemporary challenges. The use of lethal force abroad against non-state actors and individuals deemed to pose a risk to national security is one such challenge. The foregoing analysis shows that there is no perfect solution to the problem of regulating that extraordinary power. Much is at stake-for national security, human rights, the rule of law, and the international order - and that fact alone warrants caution in the way nations that use or contemplate this tactic design their legal and policy frameworks. In examining the lessons that can be gleaned from the experiences of the United States, Britain, and Israel, this paper sought to help guide nations in that daunting task.

211 An example of such a cause of action in another context is the U.S. Foreign Intelligence Surveillance Act, which provide a right of actions for people who have been subjected to unlawful surveillance. See 50 U.S.C. $§ 1810$ (2006). 